\title{
TATA KELOLA DESA WISATA BONTO UJUNG
}

\section{Penulis}

\author{
Sitti Mujahida \\ Gunawan BI \\ Fatmasari, \\ Hasyrif \\ Wa Ode Rayyani \\ Rusmin Nuryadin
}

Penerbit CV. Cahaya Bintang Cemerlang 


\title{
TATA KELOLA DESA WISATA BONTO UJUNG
}

\author{
Penulis:
}

Sitti Mujahida

Gunawan BI

Fatmasari,

Hasyrif

Wa Ode Rayyani

Rusmin Nuryadin

ISBN 978-623-6032-16-9

Editor :

Sitti Mujahida

Penyunting:

Muh Yunus Nabbi

\section{Desain Sampul dan Tata Letak}

Muh. Yunus Nabbi

Penerbit:

Percetakan CV. CAHAYA BINTANG CEMERLANG

Redaksi :

Jl. Dr. Wahidin Sudirohusodo BTN Indira Residence Blok E No. 10

Sungguminasa Kab. Gowa

No. HP: 085256649684

Email : muhyunusnabbi@gmail.com

Distributor Tunggal

Percetakan CV. CAHAYA BINTANG CEMERLANG

Jl. Dr. Wahidin Sudirohusodo BTN Indira Residence Blok E No. 10

Sungguminasa Kab. Gowa

No. HP: 085256649684/ WA: 085290480054

http//cv-cahayabintangcemerlang.co.id

Anggota UMKM Nomor : 04933-0615-20

Anggota IKAPI Nomor : 027/SSL/2020

Cetakan Pertama, Desembe 2021

Hak cipta dilindungi Undang-undang

Dilarang memperbanyak karya tulis ini dalam bentuk dan dengan cara Apapun tanpa ijin tertulis dari Penerbit. 


\section{KATA PENGANTAR}

Puji dan syukur kami panjatkan ke hadirat Allah Tuhan Yang Maha Esa, berkat petunjuk dan kehendak-Nya jualah sehingga sebuah buku yang diberi judul Tata Kelola Desa Wisata Bonto Ujung dapat terwujud. Sebagai mana adanya. Kedaireka menjadi terobosan yang digagas oleh Kementerian Pendidikan dan Kebudayaan (Kemendikbud) melalui Direktorat Jenderal Pendidikan Tinggi (Ditjen Dikti) sebagai tempat bertemunya perguruan tinggi dan dunia usaha dan dunia industri (DUDI) untuk berkolaborasi menciptakan beragam inovasi.

Program Link dan Match ini, bagi para dosen dapat meningkatkan dan memperluas wawasan dosen mengenai pelaksanaan dunia kerja dalam bidang Tridarma Perguruan Tinggi. Meningkatkan kualitas dosen, yakni meningkatkan persentase dosen yang berkegiatan tridarma, bekerja sebagai praktisi didunia industri, atau membina mahasiswa yang berhasil meraih prestasi, meningkatkan jumlah luaran penelitian dan pengabdian masyarakat dosen, yang berhasil mendapatkan rekognisi internasional atau diterapkan oleh masyarakat serta meningkatnya kompetensi dosen yang diakui industri dan dunia kerja.

Tujuan utama kehadiran buku ini adakah untuk memenuhi Luran Tambahan dari program Maching Fund Desa Bonto Ujung serta meningkatkan kompetensi dosen dalam hal tri dharma perguruan tinggi menanggulangi kurangnya buku acuan mengenai tata kelola desa wisata bagi stake holder bidang pariwisata khusunya Desa Bonto Ujung dalam mengelola desa wisatanya

Buku ini menjelaskan tentang tata kelola Desa wisata, pengembangan potensi desa wisata, manajemen SDM Desa wisata, pengemasan produk wisata, standar pengembangan desa wisata dan pemasaran desa wisata mellalui media social 
Ketidaksempurnaan pasti ada dalam buku ini. Oleh karena itu segala kritik dan saran yang dapat memperbaiki buku ini menjadi lebih baik sangat kami harapkan.

Akhirnya kami mengucapkan terima kasih kepada semua pihak yang telah membantu mewujudkan impian terbitnya buku ini, Tidak lupa penulis menyampaikan terima kasih kepada rekan-rekan dosen kolborasi beberapa perguruan tinggi yaitu Stie Amkop Makassar.Universitas Dipanegara Makassar, Sekolah Tinggi Pariwisata Tamalatea Makassar Universitas Muhammadiyah Makassar Kepala Dinas Pariwisata Jeneponto beserta stafnya , Kepala Desa Bonto Ujung dan staf, dan tidak lupa kami ucapkan terima kepada Penerbit yang sudi menjadi media penerbitan bunu ini. Semoga buku ini ada manfaatnya.

Wassalam, terima kasih, TIM Penulis 


\section{DAFTAR ISI}

HALAMAN SAMPUL ............................................................

HALAMAN REDAKSI PENERBIT ......................................... ii

KATA PENGANTAR ............................................................ii

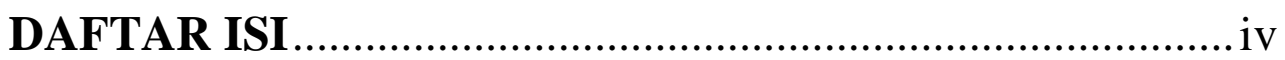

\section{BAB I PENDAHULUAN}
A. Latar Belakang .............................................................. 1
B. Ada Apa Dengan Desa Wisata ....................................... 18
C. Karakter Kampung Wisata ............................................ 22
D. Kegiatan Dalam Kampung Wisata ..................................... . 24

\section{BAB II DESA DAN DESA WISATA}
A. Klasifikasi Desa Wisata 26
B. Bagaimana Membangun Desa Wisata............................... 31
C. Infrastruktur dan SDM desa wisata ................................... .33
D. Desa Wisata …............................................................ 35
E. Desa Wisata Kebutuhan Masyarakat Perkotaan............... 46
F. Mengidentifikasi Potensi Desa Wisata............................... .49
G. Mengidentifikasi Keunikan Potensi Desa Wisata ............ .51

\section{BAB III POTENSI WISATA DESA BONTO UJUNG}
A. Potensi Atraksi Wisata Desa Bonto Ujung ....................... .56
B. Atraksi Wisata Alam ...................................................56
C. Atraksi Wisata Budaya ……………………….................58
D. Atraksi Wisata Buatan ................................................... 58

BAB IV PANDUAN TATAKELOLA DESA WISATA BONTO UJUNG
A. PerbaikanAksesibilitas
.60
B. Pembentukan Kelembagaan............................................... . 62
C. Peningkatan Kualitas Sumber Daya Manusia ................... . 74
D. Peningkatan Promosi ………………................................. . 79
E. Penataan Wajah Desa....................................................... 83
F. Pengadaan Akomodasi...................................................... 86
G. Peningkatan Kesadaran Warga ……………..................... 89
H. Pengembangan Paket Wisat............................................. .91
I. Menciptakan Branding..................................................... 95

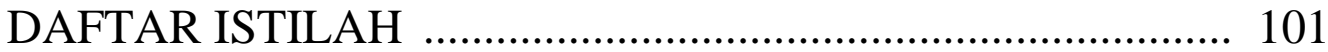


DAFTAR PUSTAKA .......................................................... 104 


\section{BAB I}

\section{PENDAHULUAN}

\section{A. Latar Belakang}

Kedaireka menjadi terobosan yang digagas oleh Kementerian Pendidikan dan Kebudayaan (Kemendikbud) melalui Direktorat Jenderal Pendidikan Tinggi (Ditjen Dikti) sebagai tempat bertemunya perguruan tinggi dan dunia usaha dan dunia industri (DUDI) untuk berkolaborasi menciptakan beragam inovasi. Sebagaimana diketahui jumlah perguruan tinggi di Indonesia lebih banyak daripada lembaga riset, sehingga melalui hal ini hasil riset dari perguruan tinggi diharapkan dapat sesuai dengan kebutuhan segala sektor. Sehingga, hasil riset yang dihasilkan oleh perguruan tinggi dapat berimplikasi dampaknya.

Dosen juga diharapkan ikut melakukan transformasi proses pembelajaran, mulai dari persiapan kurikulum sampai dengan menempatkan mahasiswa magang baik di dalam atau pun di luar negeri. Dalam Kampus Merdeka, Perguruan Tinggi akan membuka pintu selebar-lebarnya bagi industri, dunia usaha, dan dunia kerja (IDUKA) sehingga dapat dilakukan negosiasi dalam rangka meningkatkan relevansi antara kurikulum di Perguruan Tinggi dan hubungan dengan dunia kerja. Dalam Kampus Merdeka diharapkan dapat memberikan pengalaman konseptual lapangan 
yang akan meningkatkan kompetensi mahasiswa secara utuh, siap bekerja dan mengembangkan keilmuannya serta kemampuan dalam meningkatkan inovasi dan pengalaman belajar.

Desa wisata adalah suatu bentuk integrasi antara atraksi, akomodasi dan fasilitas pendukung yang disajikan dalam suatu struktur kehidupan masyarakat yang menyatu dengan tata cara dan tradisi yang berlaku (Nuryanti, 1993).Desa Wisata (rural tourism) merupakan pariwisata yang terdiri dari keseluruhan pengalaman pedesaan, atraksi alam, tradisi, unsur - unsur yang unik yang secara keseluruhan dapat menarik minat wisatawan (Joshi, 2012). Jika kedua pengertian desa wisata dipadukan, maka desa wisata adalah perpaduan antara atraksi alam, budaya, dan kreativitas masyarakat setempat didukung oleh akomodasi dan fasilitas lainnya, yang dapat menarik minat wisatawan untuk berkunjung.

Link dan Match menggali potensi yang dibutuhkan pasar tenaga kerja di masa depan. Kurikulum dan sistem pendidikan, khususnya Pendidikan Tinggi di Indonesia, sudah saatnya memenuhi tuntutan profesional. Karena selama ini lulusan di Perguruan Tinggi tidak menjamin akses ke pasar kerja dan dunia kerja.

Program Link dan Match ini, bagi para dosen dapat meningkatkan dan memperluas wawasan dosen mengenai pelaksanaan dunia kerja dalam bidang Tridarma Perguruan Tinggi. 
Meningkatkan kualitas dosen, yakni meningkatkan persentase dosen yang berkegiatan tridarma, bekerja sebagai praktisi didunia industri, atau membina mahasiswa yang berhasil meraih prestasi, meningkatkan jumlah luaran penelitian dan pengabdian masyarakat dosen, yang berhasil mendapatkan rekognisi internasional atau diterapkan oleh masyarakat serta meningkatnya kompetensi dosen yang diakui industri dan dunia kerja.

Mitra dalam hal ini adalah Desa Bonto Ujung Kabupaten Jeneponto Provinsi Sulawesi Selatan. Desa Bonto Ujung dapat mewujudkan pembangunan dari desa. Pembangunan desa merupakan upaya peningkatan kualitas hidup dan kehidupan untuk kesejahteraan masyarakat desa. Undang-Undang Nomor 6 tahun 2014 menjelaskan bahwa tujuan pembangunan desa adalah meningkatkan kesejahteraan masyarakat desa dan kualitas hidup manusia serta penanggulangan kemiskinan melalui pemenuhan kebutuhan dasar, pembangunan sarana dan prasarana desa, pengembangan potensi ekonomi lokal, serta pemanfaatan sumber daya alam dan lingkungan secara berkelanjutan.

Dalam membangun good governance saat ini, dengan mewujudkan pemerintahan yang baik menjadi sesuatu hal yang tidak dapat ditawar lagi dan mutlak harus terpenuhi. Good governance adalah penyelenggaraan pemerintahan negara yang solid dan bertanggung jawab, serta efisien dan efektif, dengan 
menjaga kesinergisan interaksi yang konstruktif diantara domaindomain negara, sektor swasta dan masyarakat. Tujuan pokok good governance adalah tercapainya kondisi pemerintahan yang dapat menjamin kepentingan pelayanan publik secara seimbang dengan melibatkan kerjasama antar semua pihak atau stakeholder (negara, masyarakat madani dan sektor swasta). UNDP (United Nations Development Program) mengemukakan bahwa prinsip yang harus dianut dan dikembangkan dalam praktek penyelenggaraan tata pemerintahan yang baik (good governance), meliputi: partisipasi (participation), penegakan hukum (rule of law), transparansi (transparency), orientasi konsensus (consensus orientation), keadilan (equity), efektivitas dan efisiensi (effectiveness and efficiency), akuntabilitas (accountability), visi strategis (strategic vision). Namun pandangan komprehensif dan lebih kontekstual di level desa bahwa good governance selama ini menekankan pada tiga poros utama yaitu, negara, masyarakat sipil dan pasar.

Desa Bonto Ujung yang berada di Kecamatan Tarowang Kabupaten Jeneponto, Desa ini memiliki potensi alam berupa yaitu Pantai Wisata Kelapa Ujung, Pantai Bonto Ujung memiliki ciri khas berupa ketersediannya kelapa muda tidak hanya terdapat pada lokasi Wisata Pantai Kelapa Ujung namun perkebunan pohon kelapa muda banyak tumbuh disekitar wilayah Desa Bonto Ujung dan letak lokasi pantai ini berada pada jalan poros daerah yang 
menghubungkan antar kabupaten. Akan tetapi, pantai tersebut kurang dikenal masyarakat sehingga sepi pengunjung. Saat ini Wisata Pantai Kelapa Ujung dikelola oleh Karang Taruna dan untuk pembiayaannya dilakukan oleh swadaya masyarakat. Permasalahannya, tidak ada regenerasi dari Karang Taruna. Ketika pemuda desa selesai menempuh sekolah menengah, sebagian besar dari mereka memilih bekerja di luar desa. Mereka menganggap mengelola Wisata Pantai Kelapa Ujung bukan merupakan pekerjaan yang menguntungkan. Hal ini menjadi masalah mengingat perlu adanya keberlanjutan dalam pengelolaan wisata agar kualitas pelayanan tetap terjaga. Permasalahan regenerasi dan kurangnya branding dari Wisata Pantai Kelapa Ujung menunjukkan betapa pentingnya pemberdayaan dan pelatihan pada organisasi kemasyarakatan desa dalam upaya mencapai keberhasilan Wisata Pantai Kelapa Ujung untuk menarik kunjungan wisatawan. Hasil yang diharapkan adalah adanya peningkatan wisatawan serta regenerasi yang baik bagi pengelolaan Wisata Pantai Kelapa Ujung.

Keberadaan Desa Wisata dalam perjalanan pembangunan pariwisata di Tanah Air sudah sedemikian penting. Ia sudah mampu mewarnai variasi destinasi yang lebih dinamis dalam suatu kawasan pariwisata sehingga pariwisata tidak selalu terjebak dalam trend pengembangan bercorak mass tourism. Dalam konteks 
kepariwisataan perkembangan Desa Wisata menjadi bagian tak terpisahkan dari pasang-surut perkembangan pariwisata. Melalui Desa Wisata, pariwisata membuktikan keberpihakannya kepada semangat pro job, pro growth, dan pro poor (pariwisata sebagai penyerap tenaga kerja pedesaan, sebagai generator pertumbuhan ekonomi wilayah, dan sebagai alat pengentasan kemiskinan).

Pariwisata merupakan salah satu sektor yang diharapkan dapat diandalkan untuk meningkatkan Produk Domestik Bruto (PDB) negara. Meskipun prosentase kontribusinya belum sebesar sektor-sektor lain. Namun, peningkatan dari tahun ke tahun mengalami pertumbuhan yang signifikan. Data dari Badan Pusat Statistik 2020 menunjukkan bahwa secara nasional kontribusi sektor ini terhadap PDB adalah sebesar 4,1\%, terjadi penurunan dari tahun 2019 yang 4,7\%. Dimana sumbangan terhadap devisa adalah sebesar Rp140 triliun, dan mampu memberikan kesempatan kerja kepada 11 juta orang. Sedangkan kinerja secara mikro menunjukkan bahwa Indeks Daya Saing Kepariwisataan Indonesia berada pada peringkat 70 dunia, kedatangan wisatawan mancanegara adalah sebesar 9 juta dan jumlah perjalanan wisatawan nusantara adalah sebesar 250 juta perjalanan. Semua angka ini jika dibandingkan dengan negara-negara ASEAN lain, Indonesia masih mengalami ketertinggalan. 
Target kinerja pariwisata dicanangkan bahwa pada tahun 2019 kinerja pariwisata secara makro harus mampu memberikan kontribusi terhadap PDB nasional sebesar 15\%, kontribusi terhadap devisa sebesar Rp280 trilyun, dan kontribusi terhadap kesempatan kerja adalah sebesar 13 juta orang. Secara mikro diharapkan bahwa pada tahun 2019 indeks daya saing kepariwisataan berada pada peringkat 30, kedatangan wisatawan mancanegara 20 juta orang, dan jumlah perjalanan wisatawan nusantara adalah sebesar 275 juta (Kemenpar RI, 2015). Untuk mewujudkan target tersebut maka sudah seharusnya dilakukan upaya pengoptimalan seluruh portofolio produk pariwisata yaitu berupa pengembangan destinasi tujuan wisata.

Pemasaran pariwisata merupakan usaha yang dilakukan stakeholders pariwisata baik swasta maupun pemerintah untuk menarik wisatawan (mancanegara dan nusantara) lebih banyak datang, lebih lama tinggal, dan lebih banyak membelanjakan dolar atau rupiahnya pada destinasi tujuan wisata yang dikunjungi. Pemasaran pariwisata ini harus dilakukan secara terus menerus dan berkelanjutan. Dalam upaya pemasaran pariwisata yang berkelanjutan perlu adanya keterlibatan masyarakat sejak awal perencanaan program. Keterlibatan masyarakat dapat meningkatkan pengetahuan, keterampilan, serta membuat 
masyarakat lebih memahami persoalan dan terbiasa mengambil keputusan.

Kementerian Pariwisata memiliki strategi dalam memasarkan pariwisata yang terangkum dalam klasifikasi kelas ordinary, extra ordinary, dan super extra ordinary. Kelas ordinary meliputi branding, advertising, dan selling. Lalu kelas extra ordinary membahas soal insentif akses, hot deals, dan CDM (Competitive Destination Model). Sedangkan kelas super extra ordinary berkenaan dengan border tourism, tourism HUB, dan LCT. Berdasarkan ketiga strategi tersebut, branding pariwisata yang tepat untuk diterapkan di Wisata Pantai Kelapa Ujung merupakan kelas ordinary. Hal ini dikarenakan sasaran wisatawan Pantai Kelapa Ujung merupakan wisatawan lokal sehingga tidak memerlukan insentif akses dan border tourism. Branding pariwisata berbasis teknologi merupakan hal yang tepat mengingat pada era digital saat ini segala informasi apapun yang kita inginkan dapat dengan mudah didapatkan. Hal ini tentunya dapat dimanfaatkan sebagai media untuk melakukan publikasi tentang pariwisata Pantai Desa Bonto Ujung terutama untuk promosi ke sosial media yang dapat dilihat khalayak luas. Branding perlu dilakukan karena hal tersebut sangat berpengaruh terhadap meningkatnya intensitas kunjungan wisatawan ke suatu destinasi dalam suatu negara . 
Branding pariwisata berbasis teknologi merupakan strategi tepat dalam menarik wisatawan khususnya kaum milenial. Pemberdayaan ini diharapkan dapat meningkatkan kualitas sumber daya manusia, khususnya organisasi masyarakat desa dalam penggunaan teknologi untuk memperkenalkan desanya melalui web, blog, dan sosial media. Selain itu, dampak pembangunan pariwisata juga diharapkan dapat meningkatkan pendapatan dan daya beli masyarakat serta menumbuhkan kesadaran pemuda desa untuk menetap dan mengembangkan potensi daerahnya.

Bentuk pemberdayaan yang dapat dilakukan kepada organisasi kemasyarakatan yang ada di Desa adalah pemberdayaan melalui pelatihan strategi pemasaran DOT, BAS dan POS. Pelatihan ini bertujuan agar organisasi kemasyarakatan dapat turut serta membangun kawasan wisata Pantai Kelapa Ujung sehingga obyek wisata dapat dikunjungi oleh wisatawan nusantara dan mancanegara sehingga berpengaruh terhadap peningkatan pendapatan dan kesejahteraan dan mendorong perekonomian masyarakat sekitar. Strategi pemasaran ini dapat dilihat pada gambar 1 berikut ini. 


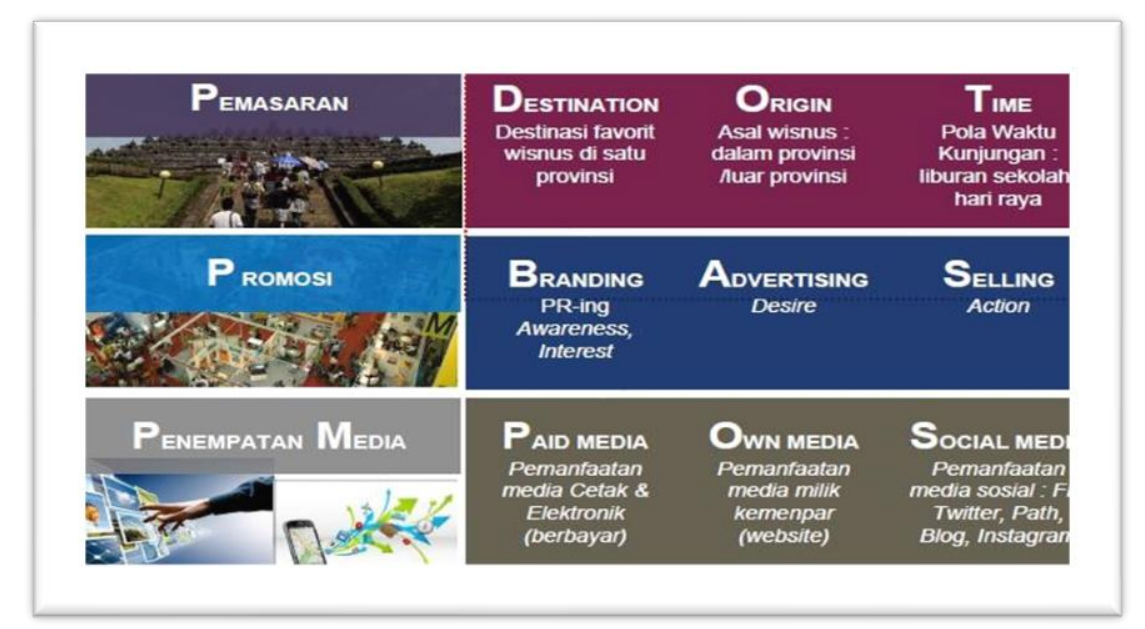

Gambar 1. Portofolio Strategi Pariwisata Nusantara

Strategi pemasaran menurut pendekatan "DOT" terdiri dari Destination (destinasi) yang berkaitan dengan produk pariwisata yang akan dipasarkan. Origin (asal) berkaitan dengan daerah asal wisatawan. Pengetahuan tentang daerah asal wisatawan akan sangat membantu memutuskan daerah yang akan dijadikan target pemasaran. Hal ini digunakan untuk memetakan profil pasar dari suatu daerah tertentu. Time (waktu) berkaitan dengan waktu-waktu tertentu yang biasa digunakan oleh wisatawan untuk berlibur. Pengetahuan tentang waktu akan membantu mengetahui kapan sebaiknya melakukan promosi wisata.

Strategi pemasaran menurut pendekatan "BAS" terdiri dari Branding yang berkaitan dengan usaha untuk meningkatkan citra daerah tujuan wisata. Hal ini dikarenakan persaingan industri pariwisata saat ini sebenarnya merupakan persaingan citra. Wisata 
Pantai Kelapa Ujung harus dikemas sedemikian rupa sehingga dicitrakan baik oleh wisatawan. Advertising berkaitan dengan kegiatan komunikasi pemasaran daerah tujuan wisata yang bersifat nonpersonal yang ditujukan kepada masyarakat brand awareness luas. Advertising memiliki tugas untuk mengkomunikasikan wisata bahari, meningkatkan image, dan meningkatkan dari suatu objek wisata. Selling berkaitan dengan upaya menarik wisatawan untuk mengunjungi destinasi tujuan wisata. Usaha ini dilakukan dengan seringnya mengikuti pameran, travel fair, dan festival.

Strategi pemasaran menurut pendekatan 'POS' terdiri dari Paid Media (media berbayar) digunakan untuk mengkomunikasikan Daya Tarik Wisata (DTW). Media berbayar dapat berupa televisi, radio, surat kabar, majalah, baliho, spanduk dan lain-lain. Strategi pemasaran melalui media berbayar bertujuan agar pesan yang disampaikan sesuai dengan khalayak sasaran secara luas. Own Media adalah media milik sendiri dapat berupa website atau saluran komunikasi lain yang merupakan milik pribadi. Social Media adalah media sosial seperti facebook, twitter, dan instagram yang digunakan untuk mengkomunikasikan suatu destinasi tujuan wisata. Pemanfaatan media sosial dapat mendongkrak popularitas daya tarik wisata. Pemuda dapat diberdayakan untuk memanfaatkan media berbayar, media milik sendiri dan media sosial agar pantai tersebut mampu dikenal masyarakat luas dan 
mendatangkan wisatawan yang melimpah baik dari daerah tersebut maupun daerah lain. Strategi pemasaran dengan menggunakan pendekatan DOT, BAS dan POS dapat dilihat pada tabel berikut ini

Tabel 1. Matriks Program DOT, BAS dan POS

\begin{tabular}{|c|c|}
\hline \multicolumn{2}{|r|}{ D O T } \\
\hline Destination & $\begin{array}{l}\text { - Perbaikan infrastruktur } \\
\text { - Peningkatan aktivitas dan atraksi } \\
\text { - Peningkatan amenities (fasilitas } \\
\text { akomodasi). }\end{array}$ \\
\hline Origin & - Penelusuran asal wisatawan \\
\hline Time & $\begin{array}{l}\text { Penelusuran tentang waktu-waktu yang } \\
\text { digunakan wisatawan untuk mengujungi } \\
\text { destinasi }\end{array}$ \\
\hline \multicolumn{2}{|r|}{ BAS } \\
\hline Branding & $\begin{array}{l}\text { Branding berdasarkan atribut produk } \\
\text { (wisata bahari dengan keindahan alam, } \\
\text { keragaman atraksi, kemudahan akses, } \\
\text { fasilitas akomodasi). Branding } \\
\text { berdasarkan heritage. }\end{array}$ \\
\hline Advertising & $\begin{array}{l}\text { - Iklan yang bertujuan untuk meningkatkan } \\
\text { brand awareness dan meningkatkan } \\
\text { image detinasi wisata bahari. } \\
\text { Iklan di media lokal seperti televisi, radio, } \\
\text { koran, majalah }\end{array}$ \\
\hline Selling & $\begin{array}{l}\text { Selling dilakukan untuk meningkatkan } \\
\text { penjualan jangka pendek. } \\
\text { - Peningkatan pameran, travel fair, } \\
\text { pemberian diskon dan reward } \\
\text { mengunjungi destinasi wisata bahari. }\end{array}$ \\
\hline \multicolumn{2}{|r|}{$\begin{array}{lll}\mathbf{P} & \mathbf{O} & \mathbf{S}\end{array}$} \\
\hline Paid Media & $\begin{array}{l}\text { - Menggunakan media-media berbayar } \\
\text { untuk mengkomunikasikan pesan yang } \\
\text { lebih banyak dan luas destinasi wisata } \\
\text { bahari. Contoh televisi, radio, koran, } \\
\text { majalah dalam bentuk publikasi. }\end{array}$ \\
\hline Own Media & 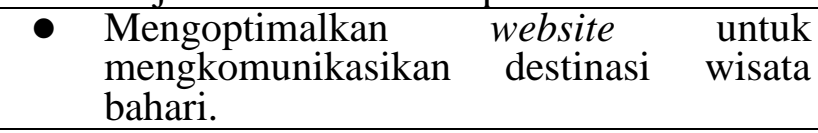 \\
\hline
\end{tabular}




\begin{tabular}{|c|c|}
\hline $\begin{array}{l}\text { Social } \\
\text { Media }\end{array}$ & $\begin{array}{l}\text { - Mengoptimalkan peran media sosial } \\
\text { melalui instagram, facebook, twitter dan } \\
\text { lain-lainnya yang bertujuan agar destinasi } \\
\text { wisata bahari dibicarakan oleh } \\
\text { masyarakat. } \\
\text { Mengidentifikasi opinion leader dari } \\
\text { media sosial untuk dijadikan sebagai } \\
\text { "jangkar" untuk mengkomunikasikan } \\
\text { destinasi wisata bahari beserta segala } \\
\text { kelebihannya pada media sosial. }\end{array}$ \\
\hline
\end{tabular}

Strategi ini dapat dilakukan bersamaan dengan pendampingan pembuatan konten media sosial informasi komunikasi, seperti blog atau weblog, instagram, dan youtube channel. Blog atau weblog merupakan kumpulan website yang memungkinkan para pembuatnya menampilkan berbagai jenis isi pada web dengan mudah, seperti karya tulis, kumpulan link internet, folder dokumen-dokumen seperti word, PDF, gambar ataupun multimedia. Dengan demikian, para pembuat web ini dapat memberikan informasi yang penting dan menarik bagi pembaca ataupun orang yang mengakses web atau blog tersebut. Pada era digital saat ini, peran sosial media sangat berpengaruh. Sosial media seperti instagram, facebook, dan youtube channel merupakan sarana yang tepat untuk melakukan promosi. Berita maupun informasi yang masuk kedalam sosial media dalam hitungan cepat dapat diketahui semua orang dan dapat diakses kapanpun dan dimanapun. Generasi milenial atau anak-anak muda saat ini juga tidak asing dengan sosial media, bahkan sosial media seperti makanan sehari-hari bagi mereka. Maka, hal ini sangat 
membantu jipenerima manka branding pariwisata Pantai Kelapa Ujung yang berada di Desa Bonto Ujung dilakukan melalui sosial media. Melalui blog dan sosial media ini, organisasi masyarakat desa dapat diberdayakan untuk dapat mengelola informasi pariwisatanya secara mudah dan murah.

Program ini dibuat agar organisasi kemasyarakatan desa memiliki rasa tanggung jawab untuk kembali membangun desa dan memberikan dampak yang lebih berkelanjutan. Salah satu strategi yang erat kaitannya dengan dunia marketing adalah dengan melakukan branding tersebut.

Selain potensi alamnya, UMKM di Desa Bonto Ujung sudah baik namun belum berkembang diakibatkan masih sulitnya memasarkan produk UMKM tersebut. Para pengeloa UMKM dapat melakukan pemasaran UMKMnya melalui blog maupun sosial media yang sama. Hal ini juga dapat mendorong perekonomian warga sekitar. Para pengelola UMKM juga dapat dikenalkan pada aplikasi desain untuk membuat tampilan produk semenarik mungkin, desain bahkan brand kemasan yang representative. Pemberdayaan ini dilakukan untuk dapat berbagi informasi baik berupa foto maupun video Pantai Kelapa Ujung dan produk usaha di media sosial. Pemberdayaan UMKM dalam pemasaran wisata Pantai Kelapa Ujung diperlukan agar wisata tersebut lebih berkembang dan dikenal publik. Hal ini dikarenakan 
sektor pariwisata merupakan sektor yang potensial untuk menjadi penggerak sektor-sektor lain seperti perekonomian dan industri.

Beberapa peluang pengembangan ekonomi di Desa Bonto Ujung yang dapat meningkatkan ekonomi desa dengan fokus pada potensi lokal yang ada antara lain: penghasil jagung serta olahan limbah jagung menjadi breket, penghasil garan beriodium, penghasil cabai terbesar di Sulawesi Selatan, penghasil Nira dari pohon lontar yang bisa dijadikan sebagai bahan pembuat gula aren atau gula padat. Peluang pengembangan jenis-jenis usaha dalam klasifikasi ini paling menarik karena kebutuhan dan potensi di desa relatif selalu tersedia.

Pemilihan dan penentuan jenis usaha yang akan dijadikan unit bisnis harus dilakukan dengan seksama dan pertimbangan yang matang. Jenis-jenis usaha yang dapat dikembangkan harus menyesuaikan dengan kebutuhan dan potensi di desa serta peluang pasar. Orientasi pembangunan desa dengan pemanfaatan program Matching Fund (Kedaireka) harapannya dapat memaksimalkan potensi lokal. Pemetaan potensi desa untuk kemudian menjadi sasaran program pengembangan dan peluang ekonomi dapat dimanfaatkan untuk memberdayakan masyarakat desa dengan inovasi dan kreativitas. Pemberian kesempatan yang seluasluasnya tidak cukup hanya melalui treatment membuka akses 
permodalan, tapi juga akses produksi, akses distribusi dan akses pasar.

Pertumbuhan ekonomi dari bawah menitikberatkan pada tumbuh dan berkembangnya sektor usaha dan industry lokal, yang mempunyai basis produksi bertumpu pada sumber daya lokal. Bentuk-bentuk usaha yang telah berkembang seperti kerajinan, pertanian, perikanan, perkebunan, peternakan, industri-industri kecil, makanan olahan sehat, adalah sektor ekonomi strategis yang melibatkan Insan Dikti dalam mewujudkan pertumbuhan ekonomi yang ada di Desa Bonto Ujung.

Beragam kendala yang menghambat pengembangan Wisata Pantai Kelapa Ujung di antaranya yaitu;

1. Destinasi Wisata Pantai Kelapa Ujung belum dikembangkan dengan baik. Destinasi merupakan produk dari sebuah jasa pariwisata. Produk yang baik adalah produk yang mampu memuaskan kebutuhan dan keinginan dari para wisatawan. Potensi produknya bagus tetapi jika tidak dikemas dengan baik sehingga kelihatan eye catching akan sulit untuk diterima oleh pasar.

2. Infrastruktur yang belum mendukung. Permasalahan infrastruktur yang belum mendukung merupakan permasalahan kuno yang belum diselesaikan dengan baik. 
Potensi produknya sangat bagus tetapi cara untuk menjangkau produk yang sangat bagus itu sulit. Untuk itu, jika menginginkan wisata Pantai Kelapa Ujung berkembang dengan baik maka permasalahan infrastruktur yang berhubungan dengan akses harus segera diselesaikan

3. Kebutuhan sumberdaya manusia (SDM) yang belum terpenuhi, jumlah sumber daya sebenarnya banyak, namun sumberdaya manusia yang sesuai dengan kebutuhan pengembangan wisata pantai yang terdapat didesa Bonto Ujung masih belum sesuai yang diharapkan. Pariwisata adalah bagian dari industri jasa, seperti SDM memiliki peran penting dalam industri jasa adalah sebagai alat vital.

4. Sarana dan prasarana yang belum optimal, pengembangan wisata Pantai Kelapa Ujung membutuhkan modal yang besar, dibutuhkan partisipasi segala sektor untuk mengembangkan objek wisata Pantai Kelapa Ujung.

Melihat potensi maka program yang dirasa cocok untuk Desa Bonto Ujung yakni “Pengembangan Wisata Pantai Kelapa Ujung Melalui Pendekatan Strategi Pemasaran DOT, BAS dan POS Di Desa Bonto Ujung Kec. Tarowang Kab. Jeneponto”.

Salah satu Luaran dan Kontribusi terhadap 8 IKU Program Kedaireka yang digagas oleh Kementerian Pendidikan dan 
Kebudayaan (Kemendikbud) melalui Direktorat Jenderal Pendidikan Tinggi (Ditjen Dikti) sebagai tempat bertemunya perguruan tinggi dan dunia usaha dan dunia industri (DUDI) adalah terbentuk Rintisan Desa Wisata Bonto Ujung dan buku tata kelola desa wisata Bonto Ujung.

\section{B. Ada Apa Dengan Desa Wisata}

Keberadaan desa wisata dalam perkembangan kepariwisataan di Tanah Air pada umumnya dan di Jeneponto pada khususnya sebagai destinasi wisata alternatif sudah sedemikian penting.Desa wisata sudah mampu mewarnai variasi destinasi wisata di suatu daerah tujuan wisata (DTW), sehingga pariwisata tidak selalu menyuguhkan atraksi wisata itu-itu saja atau biasabiasa saja (conventional attraction). Dalam lingkup kepariwisataan Jeneponto, perkembangan desa wisata menjadi bagian tak terpisahkan dari perkembangan pariwisata. Melalui desa wisata, pariwisata membuktikan keberpihakannya kepada semangat pariwisata sebagai pencipta kesempatan kerja pedesaan (pro-job), sebagai penggerak pertumbuhan ekonomi wilayah (pro-growth), dan sebagai sarana pengentasan kemiskinan (pro poor).

Dalam mengembangkan suatu desa menjadi desa wisata tidak dapat meniru mentah-mentah desa lain, tetapi harus mengembangkan keunikan yang dimiliki oleh suatu desa, dan 
keunikan inilah yang akan menjadi atraksi wisata yang berbeda dengan desa wisata lainnya.Atau dengan kata lain pengembangan desa wisata sebaiknya menggali otentisitas potensi dan keunikan sendiri dari desa wisata yang bersangkutan

Baiquni (2005) menyatakan bahwa satu hal penting yang diabaikan dalam pengembangan desa wisata adalah persoalan kapasitas kelembagaan pengelola desa wisata.Pendekatan dalam peningkatan kapasitas kelembagaan lokal (pemerintah daerah dan masyarakat) memiliki spektrum konsep dan pendekatan yang bervariasi. Ada lima aspek dan pendekatan yang perlu diperhatikan dalam pengembangan suatu desa wisata, yaitu holistic approach, participatory learning, empowerment of management, action research, dan sinergy and network, yang masing-masing aspek tersebut dijelaskan seperti berikut.

Holistic approach.Pendekatan ini melihat secara menyeluruh dimensi pembangunan atau secara holistik.Pendekatan ini berupaya mengintegrasikan berbagai elemen atau sektor pembangunan secara terpadu, sehingga perumusan masalah dan pemecahannya diselenggarakan secara kolektif dan partisipatif. Metode yang digunakan adalah system thinking sebagai cara untuk membuka pemahaman dan melakukan inovasi dalam merumuskan konteks kebijakan dan pengembangan yang tepat guna. 
Participatory learning. Pendampingan dalam pengembangan kapasitas kelembagaan lokal perlu dilakukan secara partisipatif, menggali bersama kebutuhan dan merumuskan prioritas penanganan dalam proses 'belajar bersama'. Sesungguhnya yang paling tahu persoalan adalah pelaku lokal (masyarakat dan pemerintah daerah) sendiiri, bukan konsultan atau kontraktor pembangunan yang berasal dari luar yang memiliki kepentingannya sendiri. Peran konsultan pada penguatan proses memfasilitasi pembelajaran kolektif, sehingga pemahaman permasalahan akan lebih baik dan solusinya dapat dikerjakan bersama-sama sesuai fungsi masing-masing lembaga dalam tata manajemen. Metode pembelajaran partisipatif yang dapat digunakan adalah sarasehan, lokakarya dan belajar sambil bekerja (learning by doing).

Empowerment of management. Penguatantata kelola ditujukan pada proses pembelajaran partisipatif mencakup individual dan institusional.yang oleh Ki Hajar Dewantoro disebul Triple A (Asih, Asah dan Asuh). Dalam proses belajar akan menimbulkan pencerahan (enlightment) dan penguatan atau pemberdayaan (empowerment). Kelembagaan yang kuat terdiri dari para pelakunya yang juga tercerahkan dalam belajar dan bekerja. Manajemen kelembagaan yang terus membangun pencerahan dan 
pemberdayaan akan memberikan perbaikan kinerja dalam pengembangan desa wisata.

Pengembangan kepariwisataan di Desa Bonto Ujung yang merupakan bagian integral kepariwiwataan Kabupaten Jeneponto cenderung sifatnya monoton yang mengandalkan atraksi wisata yang sudah terkenal dan itu-itu saja (conventional attraction), adanya kesan kemiripan atau kesamaan antara atraksi wisata yang satu dengan yang lainnya. Walaupun sudah mulai tampak ada suatu inovasi untuk menciptakan atraksi wisata alternaitf, tetapi rupanya belum dipersiapkan secara terencana, sehingga perkembangannya kurang terarah dan teratur.Oleh karena itu perlu dilakukan usaha terobosan dan inovasi untuk menciptakan atraksi wisata alternatif, salah satunya adalah mengembangkan desa wisata secara terencana dengan baik.

Desa Bonto Ujung adalah salah satu desa di Kecamatan Tarowang Kabupaten Jeneponto.Desa Wisata Bonto Ujung dapat ditempuh 3 Jam dari Bandara Sultan Hasanuddin Makassar Dari Kota Kabupaten Jeneponto 35 menit , desa ini dapat dengan mudah karena berada pada jalan poros kota Makassar kabupaten Bantaneg menjangkau destinasi wisata .Bila dicermati Desa Bonto Ujung memiliki keunggulan komparatif berupa potensi budaya, kreatitivtas masyarakat dan kenuikannya dibandingkan desa-desa lainnya di Kecamatan Tarowang . Desa Bonto Ujung memiliki 
ragam potensi atraksi wisata, antara lain: Wisata Bahari ,wisata budaya, wisata spiritual, wisata kampung (Ecology Tour), wisata sejarah, dsb. Bila diinginkan, Desa Wisata Bonto Ujung juga menawarkan produk wisata terintegrasi dengan desa lain yang ada di kecamatan Tarowang, dengan destinasi pilihan yang ada di sekitar Desa Wisata ini.Salah satu terobosan inovasi yang perlu dilakukan adalah mempersiapkan Desa Bonto Ujung menjadi Desa Wisata melalui perencanaan yang matang dan mantap, sehingga kelak dapat menjadi destinasi wisata alternatif di Kabupaten Jeneponto.

\section{Karakter Kampung Wisata}

Kampung wisata merupakan sebuah potensi pariwisata yang dapat menunjang perekonomian suatu daerah tertentu. Kampung wisata dapat dikatakan sebagai suatu daerah yang berpotensi wisata jika mempunyai suatu keunikan didaerah tersebut berupa kehidupan keseharian masyarakat setempat, adat istiadat, kebudayaan setempat yang menjadi daya tarik bagi wisatawan. Bebarapa karakter yang mendukung keberhasilan suatu kampung wisata sebagai berikut:

1. Sasaran wisatawan

Semakin banyak wisatawan yang datang, semakin informasi tentang daerah wisata berkembang keseluruh penjuru dunia 
2. Lokasi

Lokasi yang memilki potensi wisata yang menarik bisa menjadi daya tarik bagi para wisatawan.

3. Fasilitas wisata

Fasilitas menjadi pelangkap bagi para wisatawan yang dapat dinikmati dan menjadi objek wisata yang menimbulkan atraksi wisata.

4. Arsitektur atau suasana harus memiliki sesuatu yang istimewa sesuai dengan karakter pariwisata daerah setempat.

5. Citra

Sebuah kampung wisata merupakan gambaran karakter dari kampung itu yang membentuk identitas unik dan khas dapat dibentuk dengan menghadirkan nuansa pedesaan dan budaya setempat serta tradisi lokal kedalam kampung wisata. Kampung wisata akan berkembang dengan baik jika didukung bebarapa masyarakat yang memang mengenal dan mendukung berkembangnya suatu daerah. Yang ditempati selain itu perlu juga beberapa factor pendukung keberhasilan kampung wisata yaitu sebagai berikut :

1. Keanekaragaman fasilitas rekreasi.

2. Akomodasi yang bersih dan nyaman.

3. Lokasi yang menarik dan terjangkau.

4. Nilai budaya yang terkandung. 
5. Suasana lingkungan dan fasilitas objek yang beranekaragam.

Pengembangan konsep Kampung wisata dinilai sangat effektif dalam rangka mengenalkan serta memberi peluang sebesar - besarnya kepada masyarakat perkampungan untuk memahami esensi dunia pariwisata serta menikmati hasil dari kepariwisataan tersebut. Bagi daerah-daerah yang memiliki karakteristik dan keunikan terutama di keseharian masyarakat perkampungan maka pengembangan konsep ini sangat direkomendasikan. Ada tiga keuntungan yang utama dalam pengaplikasian konsep ini pada suatu daerah yaitu;

1. Dengan adanya kampung wisata maka pengelola harus menggali dan mempertahankan nilai adat budaya yang telah berlangsung selama puluhan tahun di kampung tersebut. Lestarinya nilai- nilai budaya merupakan daya tarik utama bagi wisatawan.

2. Masyarakat kampung yang notabene memiliki kemampuan ekonomi yang kurang dapat berperan aktif dalam kelangsungan kampung wisata. Akhir dari konsep ini tentu saja agar peningkatan taraf hidup dan perekonomian masyarakat akan lebih termaksimalkan.

\section{Kegiatan Dalam Kampung Wisata}

Kampung wisata mengalami perkembangan yang cukup 
pesat terutama dengan potensi wisata yang ada didaerah wisata yang unik. Hal ini memunculkan wisatawan untuk datang dan menikmati fasilitas atau objek wisata. Jenis Jenis Kegiatan di kampung Wisata.

1. Kegiatan berkebun

2. Membatik

3. Jalan -jalan bersepedah

4. Membuat hiasan dari janur

5. Memancing

6. Bermaen game tradisional

7. Menikmati jajanan tradisional setempat

8. Menginap di homestay

9. Belajar membuat kerajinan asli daerah setempat

10. Mandi dikali

11. Berternak hewan

12. Belajar tarian daerah setempat 


\section{BAB II}

\section{DESA DAN DESA WISATA}

\section{A. Klasifikasi Desa Wisata}

Pengembangan Desa Wisata dapat dijabarkan dalam 4 kategori, yaitu Rintisan, Berkembang, Maju dan Mandiri. Penentuan klasifikasi Desa Wisata (atau sebutan lainnya) dapat dilakukan selambat-lambatnya 2 (dua) tahun oleh Perangkat Desa yang membidangi pariwisata bersama dengan OPD yang membidangi pemberdayaan pemerintahan dan pemberdayaan masyarakat Desa. Ketentuan lebih lanjut untuk tata cara perhitungan dan evaluasi dalam penentuan klasifikasi desa wisata di Indonesia akan diatur secara terpisah dalam petunjuk teknis penentuan klasifikasi Desa Wisata.

\section{Rintisan}

Penentuan klasifikasi desa wisata rintisan dengan mengunakan kriteria sebagai berikut:

a. Masih berupa potensi yang dapat dikembangkan untuk menjadi destinasi wisata.

b. Pengembangan sarana prasarana wisata masih terbatas.

c. Belum ada/masih sedikit sekali wisatawan yang 
berkunjung dan berasal dari masyarakat sekitar.

d. Kesadaran masyarakat terhadap potensi wisata belum tumbuh.

e. Sangat diperlukan pendampingan dari pihak terkait (pemerintah, swasta).

f. Memanfaatkan Dana Desa untuk pengembangan Desa Wisata .

g. Pengelolaan desa wisata masih bersifat lokal desa

\section{Berkembang}

Penentuan klasifikasi desa wisata berkembang dengan mengunakan kriteria sebagai berikut:

a. Sudah mulai dikenal dan dikunjungi, masyarakat sekitar dan pengunjung dari luar daerah.

b. Sudah terdapat pengembangan sarana prasarana dan fasilitas pariwisata.

c. Sudah mulai tercipta lapangan pekerjaan dan aktivitas ekonomi bagi masyarakat.

\section{Maju}

Penentuan klasifikasi desa wisata maju dengan mengunakan kriteria sebagai berikut:

a. Masyarakat sudah sepenuhnya sadar akan potensi wisata termasuk pengembangannya.

b. Sudah menjadi destinasi wisata yang dikenal dan banyak 
dikunjungi oleh wisatawan, termasuk wisatawan mancanegara

c. Sarana prasarana dan fasilitas pariwisata sudah memadai.

d. Masyarakat sudah berkemampuan untuk mengelola usaha pariwisata melalui pokdarwis/kelompok kerja lokal.

e. Masyarakat sudah berkemampuan memanfaatkan dana desa untuk pengembangan desa wisata.

f. Sistem pengelolaan desa wisata yang berdampak pada peningkatan ekonomi masyarakat di desa dan pendapatan asli desa

\section{Mandiri}

Penentuan klasifikasi desa wisata mandiri dengan mengunakan kriteria sebagai berikut:

a. Masyarakat sudah memberikan inovasi dalam pengembangan potensi wisata desa (diversifikasi produk) menjadi unit kewirausahaan yang mandiri.

b. Sudah menjadi destinasi wisata yang dikenal oleh mancanegara dan sudah menerapkan konsep keberlanjutan yang diakui oleh dunia.

c. Sarana dan prasarana sudah mengikuti standar internasional minimal ASEAN

d. Pengelolaan desa wisata sudah dilakukan secara kolaboratif antar sektor dan pentahellx sudah berjalan baik.

e. Dana desa menjadi bagian penting dalam pengembangan 
inovasi diversifikasi produk wisata di desa wisata

f. Desa sudah mampu memanfaatkan digitalisasi sebagai bentuk promosi mandiri (mampu membuat bahan promosi dan menjual secara mandiri melalui digitalisasi dan teknologi).

Terdapat 4 (empat) manfaat bagi pengembangan desa sebagai desa wisata, meliputi:

a. Tingkat hidup masyarakat maju dan budaya serta tradisi dapat lestari. Manfaat pengembangan desa sebagai desa wisata yang tentunya akan langsung memberikan dampak positif bagi warga tentu saja adalah dampak positif bagi tingkat kehidupan warga, yakni tercipta lapangan kerja baru hingga peningkatan kualitas hidup masyarakat pedesaan melalui fasilitas perbaiki agar layak dikunjungi.

b. Manfaat perekonomian bagi masyarakat pedesaan. Pengembangan desa sebagai desa wisata akan menimbulkan dampak dalam perekonomian bagi masyarakat pedesaan

c. Meningkatkan keberadaan industri kecil dan menengah. Manfaat pengembangan desa sebagai desa wisata adalah peningkatan industri kecil menengah yang memanfaatkan produk local sebagai bahan bakunya

d. Promosi produk lokal. Manfaat pengembangan desa sebagai desa wisata adalah sebagai sarana promosi produk lokal 
dengan pemanfaatan sumber daya alam maupun produk lokal yang ada untuk meningkatkan penjualan

Pada pengembangan desa wisata untuk mewujudkan pembangunan pariwisata berkelanjutan, terdapat pendekatan yang perlu diperhatikan yaitu Pembangunan Pariwisata Berbasis Masyarakat dan Potensi lokal.

\section{A. Desa Wisata Sebagai Pendorong Pertumbuhan Ekonomi Desa}

Bagi masyarakat kota, panorama indahnya desa adalah idaman. Ada kesejukan, lepas dari hiruk-pikuk suasana kerja dan polusi udara, ada keunikan adat budaya desa, serta keramahan masyarakatnya. Semua itu tak bisa ditemukan di kota. Dan ketika masyarakat kota mengalami kejenuhan kerja, kemacetan di jalanan, dan kesuntukan berbagai problem perkotaan, jawabannya hanya desa. Desa yang menjanjikan ketentraman, kesejukan, keramahan dan eksotika panorama alam Secara umum beberapa hal yang dapat dieksplorasi dari potensi desa adalah: panorama keindahan alam, kerajinan lokal, seni dan budaya desa, termasuk keunikan arsitektur rumah khas desa, dan tentu keramahan penduduknya. Semua itu mempunyai multiple efek pada peningkatan ekonomi masyarakat desa. Tentu harus dengan pengelolaan yang baik dan profesional, saling membantu dalam konteks gotong-royong antar warga maupun antar lembaga desa 
dan tentu membutuhkan pula dukungan pemerintah setempat Secara sederhana saja, datangnya wisatawan ke desa, akan membutuhkan tempat tinggal/penginapan, butuh makanan, transportasi khas lokal, dan tentu fasilitas yang menghibur untuk mereka. Dan ini tentu membutuhkan kreatifitas dari pengelola desa dan tentu masyarakat desa secara umum Banyak hal yang dapat dieksplorasi dari potensi desa. Contoh sederhana, membajak sawah dengan seekor sapi, belepotan lumpur, dan sambil uro-uro (nembang Jawa), bagi orang desa adalah hal yang biasa. Tetapi bagi orang kota, ini adalah pengalaman eksotik yang sangat menarik dan tak akan ditemukan di kota

\section{B. Bagaimana Membangun Desa Wisata}

Membangun desa wisata, tidak hanya bermodalkan pemandangan indah. Ada beberapa kritertia dan hal-hal penting yang harus diperhatikan. "Alam, budaya dan kreatif adalah modal untuk desa wisata," kata Ketua Tim Percepatan Pembangunan Pariwisata Pedesaan dan Perkotaan Kementerian Pariwisata, Vitria Ariani kepada detikTravel baru-baru ini di Lantai 12 Gedung Sapta Pesona, Jl Medan Merdeka Barat, Jakarta Pusat "Soal alam dan budaya, kita tidak perlu mencemaskan karena desa-desa di Indonesia banyak yang memiliki modal tersebut dan harus dikemas dengan story telling yang bagus. Hanya saja soal kreatif, harus selaras dengan hal-hal yang mensejahterakan alam dan menjadi 
atraksi yang menarik Setelah 3 modal tersebut, selanjutnya adalah soal komitmen. Komitmen masyarakat desa dan pemerintahnya untuk menggembangkan dan merawat desanya sebagai desa wisata "Harus ada CEO commitment dari kepala desa, Pokdarwis (Kelompok Sadar Wisata) dari masyarakatnya dan Genpi (Generasi Pariwisata Indonesia) anak-anak mudanya. Kepala desa bisa meneruskan kepada bupati dan bupati setempat harus mengeluarkan SK untuk desa wisatanya

Bagi masyarakat kota, panorama indahnya desa adalah idaman. Ada kesejukan, lepas dari hiruk-pikuk suasana kerja dan polusi udara, ada keunikan adat budaya desa, serta keramahan masyarakatnya. Semua itu tak bisa ditemukan di kota. Dan ketika masyarakat kota mengalami kejenuhan kerja, kemacetan di jalanan, dan kesuntukan berbagai problem perkotaan, jawabannya hanya desa. Desa yang menjanjikan ketentraman, kesejukan, keramahan dan eksotika panorama alam Secara umum beberapa hal yang dapat dieksplorasi dari potensi desa adalah: panorama keindahan alam, kerajinan lokal, seni dan budaya desa, termasuk keunikan arsitektur rumah khas desa, dan tentu keramahan penduduknya. Semua itu mempunyai multiple efek pada peningkatan ekonomi masyarakat desa. Tentu harus dengan pengelolaan yang baik dan profesional, saling membantu dalam konteks gotong-royong antar warga maupun antar lembaga desa 
dan tentu membutuhkan pula dukungan pemerintah setempat Secara sederhana saja, datangnya wisatawan ke desa, akan membutuhkan tempat tinggal/penginapan, butuh makanan, transportasi khas lokal, dan tentu fasilitas yang menghibur untuk mereka. Dan ini tentu membutuhkan kreatifitas dari pengelola desa dan tentu masyarakat desa secara umum Banyak hal yang dapat dieksplorasi dari potensi desa. Contoh sederhana, membajak sawah dengan seekor sapi, belepotan lumpur, dan sambil uro-uro (nembang Jawa), bagi orang desa adalah hal yang biasa. Tetapi bagi orang kota, ini adalah pengalaman eksotik yang sangat menarik dan tak akan ditemukan di kota

\section{Infrastruktur dan SDM desa wisata}

Membangun desa-desa menjadi destinasi-destinasi wisata bukan pekerjaan mudah. Bukan hanya "banyak persoalan", tapi "sangat banyak persoalan" yang harus diselesaikan dan sangat banyak PR yang harus dituntaskan terlebih dahulu, baik oleh pemerintah desa, asosiasi desa wisata, pemerintah daerah, pemerintah pusat, dan stakeholder lainnya pemerintah daerah melalui Dinas Pariwisata pun tidak perlu membatasi pemahaman bahwa konsep desa wisata hanya bisa dilakukan di desa-desa tertentu. Karena sejatinya setiap desa memiliki potensi untuk dijadikan komoditas wisata unggulan. Sebut saja misalnya desa dengan keindahan dan keunikan alam, tentu akan menjadi desa wisata alam. Jika desa tersebut memiliki 
keunikan tradisi dan budaya tentu bisa menjadi destinasi desa wisata budaya. Jika desa tersebut memiliki menu makanan dan minuman khas tradisional yang unik baik dari bahan, rasa, dan penyajiannya bisa dijadikan destinasi desa wisata kuliner. jika desa tersebut memiliki kerajinan-kerajinan khas nan unik bisa menjadi destinasi wisata suvenir desa. Atau jika desa tersebut memiliki peninggalan-peninggalan yang mempunyai nilai sejarah yang tinggi atau situs sejarah/prasejarah bisa menjadi tujuan wisata sejarah desa. Bahkan jika desa itu memiliki keunggulan hasil bumi atau hasil laut misalnya pertanian, perkebunan, dan perikanan (contoh wisata petik apel, petik strawberry, petik tomat, cabai, dan sayuran lain), peluang menjadi desa wisata pun masih sangat terbuka lebar. Karena dunia wisata dalam perspektif kekinian banyak mengalami perkembangan yang cukup signifikan. Apapun bisa dijadikan destinasi wisata yang mendatangkan keuntungan ekonomi bagi warga sekitar, asal jeli melihat dan memanfaatkan peluang Semua desa bisa melakukan dan mengembangkan desa wisata, dengan berbagai skala pasar. Dari pemahaman awal yang demikian, maka selanjutnya otoritas dan para pihak harus mulai bekerja sama, mulai dari tahap identifikasi keunggulan sampai pada tahap promosi dan tahap pemasaran. Pemahaman yang sama terkait urgensi desa wisata dalam meningkatkan taraf hidup 
masyarakat desa tersebut tentu harus diikuti dengan kebijakan yang linier dengan kepentingan desa wisata.

\section{Desa Wisata}

Penetapan Desa Wisata melalui beberapa tahapan proses sebagai berikut:

1. Pengusulan Penetapan desa wisata dilakukan oleh kelompok masyarakat kepada pemerintah desa yang disetujui melalui musyawarah

2. Hasil Musyawarah keputusan kepala desa disampaikan kepada pengembangan desa wisata kepada OPD yang menangani urusan pariwisata

3. OPD melakukan verifikasi, uji kelayakan terhadap usulan desa wisata, yang memenuhi persyaratan selanjutnya ditetapkan dengan keputusan Bupati/ Walikota

usulan Desa wisata dilaksanakan secara kolaboratif lintas Organisasi Perangkat Daerah (OPD) yaitu:

1. OPD yang menangani bidang pariwisata.

2. OPD yang menangani bidang administrasi pemerintahan dan pemberdayaan masyarakat Desa

Wilayah perdesaan memiliki ciri-ciri : (1) perbandingan tanah dan manusia (man land ratio) relative besar; (2) lapangan 
kerja agraris; (3) hubungan penduduk yang akrab; dan (4) sifat yang menurut tradisi (tradisional). Akar budaya desa ditunjukan oleh adanya ciri-ciri kebersamaan, kekeluargaan, dan kegotongroyongan, sehingga pengembangan perdesaan sebagai objek dan atraksi wisata biasanya menggunakan sumber daya yang ada seperti lahan, budaya, masyarakat dan alam.

Satu dasa warsa belakangan ini pergeseran paradigma pembangunan dari top down planning menjadi bottom up planning. Paradigma ini muncul di berbagai sektor pembangunan termasuk dalam bidang pembangunan pariwisata. Kedua model pembangunan ini banyak didiskusikan oleh kalangan akademisi maupun praktisi, namun hingga kini belum menghasilkan suatu konklusi.Untuk negara yang sedang berkembang di mana infrastruktur organisasi perencanaan yang masih sangat lemah dan juga kemampuan sumber daya manusia yang belum merata, ada kecenderungan untuk menggabungkan kedua sistem pendekatan tersebut.

Di sektor pariwisata, model pembangunan bottom up planning, sejalan dengan paradigma pariwisata yang bercirikan kerakyatan, dan memunculkan berbagai sebutan yaitu: pariwisata inti rakyat, pariwisata kerakyatan, resource community basemanagement atau community management (Korten,1986), sehinggaakhirnya mengarah pada pengembangana desa wisata, 
desa wisata terpadu dan Wisata Perdesaan sebagai salah satu bentuk pengembangan pariwisata berkelanjutan yang memiliki pasar tersendiri (Adhisakti, 2000). Paradigma pariwisata kerakyatan dalam berbagai bentuknya telah lama menjadi paradigma alternatif sebagai kegagalan model modernisasi yang diterapkan di negara-negara berkembang termasuk Indonesia yang memiliki banyak kelemahan karena selalu mengacu pada pertumbuhan dan perkembangan fisik dan kurang memperhatikan masalah sosial budaya masyarakat. Terkait dengan pemikiran tersebut, maka desa-desa yang memiliki keunikan mulai dilirik untuk dipersiapkan menjadi desa wisata maupun wisata perdesaan oleh pemerintah maupun pelaku-pelaku pariwisata.

Pariwisata perdesaan adalah suatu wilayah perdesaan yang menawarkan keseluruhan suasana yang mencerminkan keaslian perdesaan, baik dari kehidupan sosial ekonomi, sosial budaya, adat-istiadat keseharian, arsitektur bangunan maupun struktur tata ruang desa yang khas atau kegiatan perekonomian yang unik dan menarik serta mempunyai potensi untuk dikembangkannya berbagai komponen kepariwisataan (atraksi, akomodasi, makan, minum, dan lain-lain) (Depbudpar, 2000). Pariwisata perdesaan termasuk ke dalam jenis industri kecil, karena melayani pasar kecil, memerlukan modal relatif lebih sedikit, memanfaatkan sumber daya lokal, dan tidak memerlukan sumberdaya yang canggih dan 
mahal. Ramuan utama pariwisata perdesaan adalah keaslian, keunikan, rasa khas daerah, dan kebanggaan daerah yang berwujud gaya hidup dan kualitas hidup masyarakatnya. Keaslian dipengaruhi oleh keadaan ekonomi, fisik, dan sosial daerah perdesaan tersebut, misalnya tata ruang, warisan budaya, kegiatan pertanian, bentang alam, jasa, peristiwa sejarah dan budaya yang penting, serta pengalaman yang eksotik khas daerah.Secara khusus berkaitan dengan perilaku, integritas, keramah-tamahan, dan kesungguhan penduduk yang tinggal di daerah tersebut. Dengan demikian permodelan pariwisata perdesaan dapat mengembangkan identitas dan ciri khas daerah sesuai dengan prinsip dan tata cara adat setempat. Adapun caranya adalah dengan mengembangkan mutu produk wisata perdesaan, pengembangan sumber daya manusia untuk menjadi wirausaha pariwisata perdesaan, pembuatan kelompok usaha lokal, dan memberikan kesempatan pada masyarakat setempat untuk ikut mengendalikan strategi dan pelaksanaan kegiatan tersebut (Nasikum,1997, Fagence, 1997).

Di pihak lain, Lane, 1994 (dalam Page and Geertz, 1997) mengemukakan bahwa terdapat kesulitan dalam menentukan batasan atau definisi pariwisata perdesaan karena beberapa faktor, yaitu: (1) daerah perdesaan masih sukar ditentukan batasannya, (2) tidak semua pariwisata yang terjadi di perdesaan termasuk jenis pariwisata perdesaan, itu mungkin jenis pariwisata kota hanya saja 
letaknya di daerah perdesaan,menurut sejarah, pariwisata sebagian besar berlangsung di perkotaan karena sebagian besar wisatawan tinggal di daerah perkotaan, pariwisata dapat mempengaruhi daerah perdesaan, sehingga terjadi perubahan budaya dan ekonomi, (4). bentuk pariwisata perdesaan yang dikembangkan masing-masing daerah berbeda-beda, (5) daerah perdesaan itu sendiri mengalami perubahan yang sangat kompleks akibat pengaruh dari pasar global, komunikasi, dan telekomunikasi, dan (6) pariwisata perdesaan terdiri dari berbagai macam aktivitas yaitu, pariwisata alam, jalan-jalan, mendaki, berkuda, petualangan, olah raga dan kesehatan, berburu, belajar tentang kebudayaan daerah setempat. Selanjutnya juga disebutkan bahwa pariwisata perdesaan harus memperhatikan hal-hal seperti:

a. Lokasinya harus di daerah perdesaan.

b. Fungsi perdesaan dikembangkan dalam suasana perdesaan yang memiliki ciri khusus, yaitu usaha kecil, ruang terbuka, berhubungan dengan alam dan keaslian kegiatan masyarakat tradisional.

c. Bersifat tradisional, berkembang secara perlahan dan berhubungan dengan masyarakat lokal.

d. Skala perdesaan baik bentuk bangunan maupun pengaturan harus selalu dalam skala kecil. 
e. Menyajikan bentuk yang komplek dari lingkungan perdesaan, ekonomi, sejarah, dan lokasinya. Keberhasilan pariwisata perdesaan sangat dipengaruhi oleh intensitas kegiatan, lokasinya, manajemen, dan dukungan dari masyarakat lokal dan harus sesuai dengan keinginan masyarakat lokal (Lane,1994 dalam Page and Getz,1997). Pariwisata perdesaan harus sesuai dengan keinginan masyarakat lokal dan tidak direncanakan secara sepihak, mendapat dukungan dari masyarakat setempat bukan individu atau kelompok tertentu. Inisiatif menggerakan modal usaha, profesionalisme, pemasaran, citra yang jelas harus dikembangkan karena keinginan wisatawan adalah mencari hal yang spesial dan produk yang menarik (Page and Getz,1997).

Dilihat dari perspektif kehidupan masyarakatnya, pariwisata perdesaan merupakan suatu bentuk pariwisata dengan objek dan atraksi berupa kehidupan desa yang memiliki ciri-ciri khusus dalam masyarakatnya, panorama alam dan budayanya, sehingga mempunyai peluang untuk dijadikan komoditi bagi wisatawan, khususnya wisatawan asing. Kehidupan desa sebagai tujuan wisata adalah desa sebagai objek sekaligus juga sebagai subjek dari kepariwisataan yaitu sebagai penyelenggara sendiri dari berbagai aktivitas kepariwisataan, dan hasilnya akan dinikmati oleh masyarakatnya secara langsung. Oleh karena itu peran aktif dari 
masyarakat sangat menentukan kelangsungan kegiatan perdesaan ini (Subagyo,1991).

Tampaknya yang terpenting dari pembangunan pariwisata perdesaan adalah sebagai antisipasi terhadap pariwisata konvensional yang cenderung menimbulkan konflik antara sumber daya, masyarakat, dan wisatawan. Ardika (2001) mengungkapkan bahwa kebijakan pengembangan perdesaan melalui usaha-usaha kepariwisatan antara lain: desa wisata, wisata perdesaan, jasa akomodasi, jasa boga dan pujasera, pelayanan transportasi, penyediaan cendramata, dan bahan konsumsi melalui berbagai usaha agar masyarakat mampu dan mau memasuki bidang-bidang usaha tersebut.

Pembangunan pariwisata perdesaan diharapkan menjadi suatu model pembangunan pariwisata berkelanjutan sesuai dengan kebijakan pemerintah di bidang pariwisata. Di mana sejak publikasi Our Common Future atau "The Brungtland Report" tahun 1987 yang disusun oleh komite dunia untuk Lingkungan dan Pembangunan (WCED), kemampuan keberlanjutan menjadi tujuan pembangunan yang diterima secara umum.

Penelitian Putra (2000) tentang "Pengembangan Model Pariwisata Perdesaan sebagai Alternatif Pembangunan Berkelanjutan" menyatakan bahwa pada dasarnya pariwisata perdesaan masih dikategorikan sebagai model pariwisata baru yang 
dikenal dengan nama pariwisata minat khusus (special interest tourism). Pariwisata perdesaan lebih mengedepankan derajat keunikan dan kekhasan dari suatu daerah, baik dalam kondisi alam lingkungannya, lingkungan sosial mauipun budaya.Secara rinci disebutkan potensinya berupa topografi tanahnya berupa perbukitan, persawahan yang indah dan membentang, lahan pertanian dan ladang yang subur dengan ditunjang berbagai jenis kerajinan dan kesenian yang dilakukan oleh masyarakatnya.Potensi yang belum dikembangkan dapat dikemas menjadi paket produk wisata yang dapat ditawarkan kepada wisatawan asing, sehingga dapat sebagai alternatif pekerjaan serta menambah pendapatan masyarakat setempat.

Dalam mengembangkan pariwisata perdesaan dan pertanian secara berlanjut, hendaknya memenuhi tiga prinsip dasar pembangunan yaitu holistic approach, futurity, dan equity.Jadi pembangunan harus memperhatikan aspek politik global, sosio ekonomi, dan aspek lingkungan. Mempertimbangkan kelangsungan hidup generasi yang akan datang dan mengandung prinsip persamaan di mana keberadaan tamu, masyarakat lokal, dan semua yang terlibat mempunyai kedudukan dan peluang yang sama (Kusmayadi, 2000). Di lain pihak Palupi dan Inkadijaya (2000) menjelaskan bahwa dalam pembangunan pariwisata di perdesaan, peran serta masyarakat merupakan kunci utama untuk mencapai 
sukses. Karena itu pelatihan yang sesuai bagi peningkatan keterampilan masyarakat secara singkat dan terarah sesuai kebutuhan lokal sangat diperlukan.Elemen pelatihan yang dilakukan harus diupayakan sesederhana mungkin mengingat pada umumnya kondisi sumber daya manusia di pedesaan relatif rendah.Namun Fandel (2003) menyatakan bahwa skenario pengembangan wisata perdesaan adalah dengan mengoptimalkan lembaga lokal, program pengembangan sumber daya manusia, membuat program pemasaran pariwisata, dan berbasis pada budaya masyarakat petani.Konsep pariwisata kerakyatan telah diaplikasikan dalam bentuk desa wisata seperti Desa Wisata Sebatu, Jatiluwih, dan Penglipuran di Bali sebagai proyek percontohan. Kemudian dilanjutkan dengan penelitian awal terhadap desa-desa di Bali lainnya yang mempunyai keunikan untuk dijadikan Desa Wisata. Di masing-masing desa yang diteliti menunjukan keanekaragaman potensi, sehingga akan terlihat bentuk Desa wisata dengan basis yang berbeda dan bervariasi.

Solusi lain untuk merealisasikan konsep pariwisata kerakyatan adalah dengan merencanakan wisata perdesaan, artinya desa-desa yang potensial dipromosikan untuk kunjungan wisata dengan berbagai aktivitas keasliannya. Dengan demikian masyarakat akan merasakan pemerataan hasil dari pariwisata dan akan dapat menggugah masyarakat untuk membuka usaha 
pariwisata, sehingga pendapatan meningkat dan berkurangnya kecemburuan sosial dalam masyarakat. Sebaliknya pariwisata kerakyatan justru ingin menyeimbangkan (harmonis) antara sumberdaya, masyarakat, dan wisatawan (Natori, 2001). Dalam hal ini masyarakat lokal sebagai pelaku utama (actor) pembangunan pariwisata kerakyatan, karena yang paling tahu potensi wilayahnya atau karakter dan kemampun unsur-unsur yang ada dalam desa termasuk indigenous knowledge yang dimiliki oleh masyarakat, sehingga pembangunan yang akan direncanakan sesuai keinginan masyarakat lokal: dari, oleh, dan untuk rakyat (Adhisakti, 2001).

Natori (2001) menyatakan bahwa tolok ukur pembangunan pariwisata berbasis kerakyatan adalah terciptanya hubungan yang harmonis antara masyarakat lokal, sumber daya alam/budaya, dan wisatawan. Hal ini dapat dilihat dari :

1) Adanya peningkatan antusiasme pembangunan masyarakat melalui pembentukan suatu wadah organisasi untuk menampung segala aspirasi masyarakat, melalui sistem kolaborasi antara pemerintah dan masyarakat lokal.

2) Adanya keberlanjutan lingkungan fisik yang ada di masyarakat, caranya adalah melalui konservasi, promosi dan menciptakan tujuan hidup yang harmonis antara sumber daya alam, sumber daya budaya, dan sumber daya manusia. Penemuan kembali potensi sumber daya alam, dan sumber daya budaya.

3) Adanya keberlanjutan ekonomi melalui pemerataan dan keadilan dalam menikmati hasil-hasil pembangunan. 
4) Membangun sistem yang menguntungkan masyarakat seperti sistem informasi yang dapat digunakan bersama-sama.

5) Menjaga kepuasan wisatawan melalui pelayanan yang lebih baik, pengadaan informasi yang efektif, efisien, tepat guna serta mengutamakan kenyamanan bagi wisatawan. Kemudian hubungan antara komponen pembangunan pariwisata berbasis kerakyatan seperti diuraikan sebelumnya disajikan pada gambar 2.1 berikut.

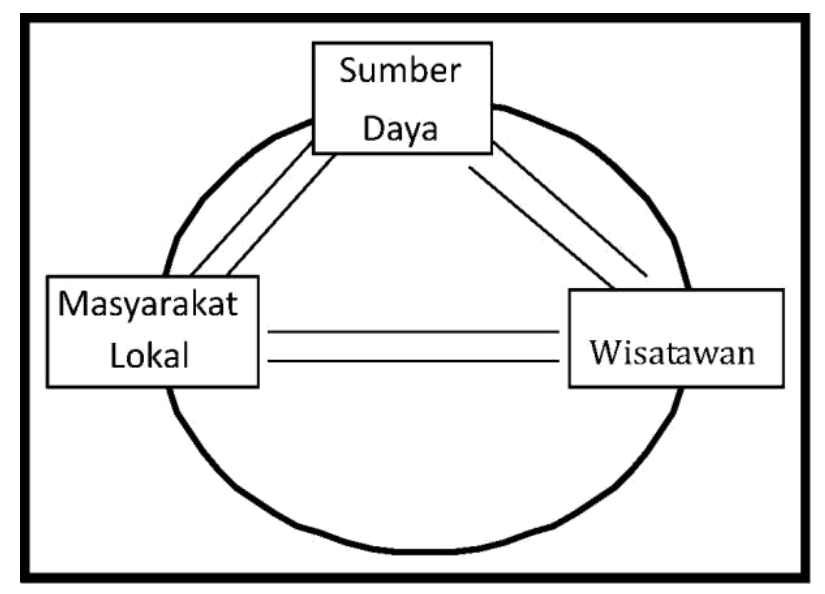

Gambar 2.1.

Pengembangan Pariwisata Berbasis Kerakyatan (Sumber: Natori, 2000)

Bentuk-bentuk pengembangan pariwisata kerakyatan dapat dilakukan dengan tiga cara yaitu; (1) swadaya (sepenuhnya dari masyarakat); (2) kemitraan (melalui pengusaha besar/kecil atau sistem bapak angkat); dan (3) pendampingan oleh LSM atau pihak perguruan tinggi selama masyarakat dianggap belum mampu untuk mandiri, namun apabila mereka sudah dianggap mampu mandiri 
maka secara pelan-pelan ditinggalkan oleh pendamping (Depbudpar, 2000; Ardika, 2001). Untuk mencapai pariwisata kerakyatan yang berkelanjutan dilakukan dengan berbagai pendekatan sistem yang utuh dan terpadu, bersifat interdisipliner, participatory, danholistik antara komponen terkait.

\section{E. Desa Wisata Kebutuhan Masyarakat Perkotaan}

Sebuah desa dikatakan layak sebagai destinasi wisata jika minimal memiliki tiga komponen utama yang saling berkaitan. Komponen tersebut adalah atraksi/atraksi unik, paket wisata, dan fasilitas. Atraksi desa wisata merupakan komponen pertama dan menjadi pondasi desa wisata.Persepsi tentang pariwisata biasanya menghambat pengelola desa wisata untuk menentukan potensi atraksi desanya.Kebanyakan pemerintah desa atau pengelola desa masih berpatokan bahwa tempat wisata adalah hal yang indah dan harus dipenuhi fasilitas lengkap.Persepsi tentang objek wisata modern tersebut menghalangi ide pengembangan desa wisata. Biasanya persepsi tersebut membentuk tembok besar, tinggi dan kokoh bernama 'susahnya mencari dana' untuk mengembangkan potensi desa wisata.

Kalau mau berkata jujur, desa wisata merupakan destinasi khusus.Artinya dia bukan destinasi wisata untuk semua kalangan masyarakat seperti objek wisata modern, melainkan lebih pada 
jenis wisata nostalgia dan edukasi yang rata-rata menyasar pada kelompok masyarakat dari perkotaan dan anak-anak. Dikatakan sebagai wisata nostalgia karena sebagian besar pangsa pasarnya adalah mereka yang dulunya adalah masyarakat desa yang sekarang terjebak dalam kehidupan kota. Bagi mereka, melihat dan merasakan kembali suasana kehidupan desa adalah hal yang kembali menjadikan hidup menjadi lebih segar (refresh) dan lebih kreatif-produktif (recreat). Mereka akan lebih memilih bau sapi (wisata desa agrarian) atau bau amis ikan (wisata desa pesisir) saat bangun pagi dari pada aromaterapi dan parfum hotel. Mereka juga akan lebih memilih suara jangkrik dan serangga sebagai pengantar tidur di malam hari atau angin persawahan daripada suara musik di objek wisata modern.

Kenapa dikatakan juga sebagai wisata edukasi? Ini lebih berkaitan dengan keberlanjutan pengetahuan tentang perdesaan dan kehidupannya yang susah untuk didapatkan dalam pendidikan formal perkotaan. Kalaupun diberikan pengetahuan tentang perdesaan, orang tidak akan pernah tahu sebenarnya jika mereka tidak singgah dan merasakannya langsung. Pengetahuan dan pengalaman langsung inilah yang ditawarkan desa wisata pada masyarakat modern, terutama anak-anak dan mereka yang belum pernah mengenal secara langsung kehidupan desa, termasuk para turis mancanegara. Misalkan anda adalah seorang desa yang telah 
berhasil hidup di kota, apakah anda akan begitu saja mencabut akar sejarah anda pada anak-cucu anda? Atau apakah sebaliknya, anda akan dengan sangat bangga menunjukkan pada mereka bahwa anda berasal dari desa yang penuh dengan eksotisme dan kebersahajaan. Kalau iya, dimanakah anda akan membawa anak-anak anda? Ya, desa wisata adalah jawabannya. Tentang anak-anak perkotaan yang selalu hidup dalam tembok rumah-sekolah dan juga tembok virtual internet-game. Apakah menurut anda sekali waktu mereka membutuhkan untuk mandi di sungai, memancing di sungai/laut, mencari makan untuk ternak, menggembalakannya dan memberikan makanan langsung pada ternak, memerah susu di pagi hari atau sekedar bermain gasing, gobag sodor, egrang, layanglayang. Kalau iya, dimanakah anda akan membawa anak-anak anda? Sekali lagi, desa wisata adalah jawabannya

Desa wisata adalah sebuah kebutuhan bagi masyarakat modern perkotaan.Potensi historis serta edukasinya bagi sebagian orang jauh lebih bermakna untuk mengisi waktu liburan daripada hingar-bingar objek wisata perkotaan.Inilah yang disebut potensi, inilah yang disebut ciri khas.Jika jenis perdesaan itu beragam, maka semua desa memiliki potensinya sendiri untuk menjadi destinasi wisata.Berbeda dengan objek wisata modern yang membutuhkan make-up untuk disebut layak, desa wisata justru 
dicari karena dia natural tanpa sentuhan, dan bersahaja dalam kejujuran.

\section{F. Mengidentifikasi Potensi Desa Wisata}

Mengidentifikasi suatu desa yang memiliki potensi dikembangkan menjadi sebuah desa wisata, haruslah dilakukan tahapan sebagai berikut:

a. Lakukan pemetaan desa dari calon desa wisata. Pemetaan ini dilakukan untuk dapat mengidentifikasi desa yang memiliki potensi dikembangkan sebagai desa wisata, selanjutnya lakukan analisis deskriptif kualitatif dan telaah dokumen.

b. Identifikasi calon desa wisata yang bersangkutan, apakah sudah pernah memperoleh bantuan PNPM Mandiri Pariwisata, mengingat banyak calon desa wisata menjadi desa wisata berkat bantuan PNPM Mandiri Pariwisata. Analisis menggunakan analisis deskriptif kualitatif.

c. Analisis karateristik dan ukuran keberhasilan pengembangan desa wisata berbasis masyarakat (community based-tourism) dari calon desa wisata. Analisis ini dilakukan untuk mengetahui karateristik dari community based-tourism yang berlaku di dalam pengembangan desa wisata tersebut. Community basedtourism ini memiliki peran yang sangat penting dalam pengembangan desa wisata. Analisis ini menggunakan analisis deskriptif kualitatif. 
d. Analisis manfaat pengembangan desa wisata jika memerlukan bantuan PNPM Mandiri Pariwisata. Analisis ini dilakukan untuk mengetahui manfaat yang didapat dari bantuan PNPM Mandiri Pariwisata. Aspek yang dibahas adalah manfaat kepada masyarakat pelaku wisata, desa wisata, kelompok sadar wisata, dan biro perjalanan pemasok wisatawan. Analisis ini menggunakan analisis deskriptif kualitatif dan observasi lapangan (dokumentasi);

e. Rumuskan pola pengembangan community based tourism. Rumusan pola pengembangan ini merupakan kumpulan atau hasil temuan dari analisis sebelumnya yang dirumuskan dalam bentuk pola yang mendeskripsikan pola pengembangan yang terjadi di desa wisata.

f. Analisis sistem dan elemen kepariwisataan dari calon desa wisata. Analisis ini dilakukan untuk mengetahui sistem dan elemen yang saling terintegrasi yang dimiliki oleh calon desa wisata yang kemungkinan berhasil dalam pengembangannya dengan bantuan PNPM Mandiri Pariwisata. Analisis ini meliputi atraksi wisata, akomodasi, infrastruktur, promosi, minat wisatawan dan masyarakat. Analisis ini menggunakan analisis deskriptif kualitatif dan observasi lapangan (dokumentasi). 


\section{G. Mengidentifikasi Keunikan Potensi Desa WIsata}

Obyek wisata adalah segala sesuatu yang ada di daerah tujuan wisata yang merupakan atraksi agar orang-orang mau datang berkunjung ke tempat tersebut. Menurut SK. MENPARPOSTEL No.: KM. 98/PW.102/ MPPT-87, Obyek Wisata adalah semua tempat atau keadaan alam yang memiliki sumber daya wisata yang dibangun dan dikembangkan, sehingga mempunyai atraksi dan diusahakan sebagai tempat yang dikunjungi wisatawan.

Atraksi Wisata sejatinya merupakan kata lain dari obyek wisata, namun sesuai peraturan pemerintah Indonesia tahun 2009 kata obyek wisata sudah tidak relevan lagi untuk menyebutkan suatu daerah tujuan wisatawan, maka digunakanlah kata "Atraksi Wisata", maka untuk mengetahui apa arti dan makna dari atraksi wisata di bawah ini adalah beberapa definisi/pengertian mengenai DayaTarik Wisata menurut beberapa ahli :

1) Berdasarkan Undang-Undang Republik Indonesia No. 10 tahun 2009, Atraksi Wisata dijelaskan sebagai segala sesuatu yang memiliki keunikan, kemudahan, dan nilai yang berupa keanekaragaman kekayaan alam, budaya, dan hasil buatan manusia yang menjadi sasaran atau kunjungan wisatawan. 
2) Yoeti dalam bukunya "Pengantar Ilmu Pariwisata" tahun 1985 menyatakan bahwa atraksi wisata atau atraksi wisata (tourist attraction), istilah yang lebih sering digunakan, yaitu segala sesuatu yang menjadi atraksi bagi orang untuk mengunjungi suatu daerah tertentu.

3) Pendit dalam bukunya "Ilmu Pariwisata" tahun 1994 mendefiniskan atraksi wisata sebagai segala sesuatu yang menarik dan bernilai untuk dikunjungi dan dilihat.

4) Atraksi Wisata adalah segala sesuatu yang menjadi tujuan kunjungan wisatawan.

5) Atraksi Wisata adalah sifat yang dimiliki oleh suatu obyek berupa keunikan, keaslian, kelangkaan, lain dari pada yang lain memiliki sifat yang menumbuhkan semangat dan nilai bagi wisatawan" (budpar)

6) Atraksi wisata adalah suatu bentukan dan fasilitas yang berhubungan, yang dapat menarik minat wisatawan atau pengunjung untuk datang ke suatu daerah atau tempat tertentu.

Dari beberapa pengertian di atas dapat disimpulkan bahwa Atraksi Wisata (DTW) merupakan segala sesuatu yang dimiliki oleh setiap objek wisata maupun tujuan wisata yang memiliki ciri khas yang mampu menarik simpati wisatawan untuk mengunjungi tempat wisata tersebut. Mengembangkan suatu desa menjadi desa 
wisata harus menggali dan mengidentifikasi potensi-potensi desa yang dimiliki (alam, budaya, buatan manusia) yang kelak menarik dilihat dan dikunjungi oleh wisatawan yang memang memiliki keunikan tidak ada duanya di tempat lain. Setiap desa wisata pasti memiliki keunikan yang tiada duanya di desa lain, menarik dikemas menjadi paket wisata dan ditawarkan kepada wisatawan, baik melalui sebuah brosur yang ditawarkan kepada biro perjalanan, maupun dipromosikan melalui media on-line yang dikenal dengan website.

Dalam UU No. 9 tahun 1990 tentang kepariwisataan disebutkan bahwa atraksi wisata adalah suatu yang menjadi sasaran wisata terdiri atas :

1) Atraksi wisata alam, yaitu atraksi wisata ciptaan Tuhan Yang Maha Esa yang berwujud sumberdaya alam, flora dan fauna, yang berpotensi serta memiliki atraksi bagi pengunjung baik dalam keadaan alami maupun setelah ada usaha budi daya.

2) Atraksi wisata budaya, yaitu pola pikir dan tingkah laku manusia keseharian, seperti adat-istiadat.

3) Atraksi wisata buatan manusia, yaitu atraksihasil karya manusia yang berwujud museum, peninggalan sejarah, seni dan budaya, wisata agro, wisata buru, wisata petualangan alam, taman rekreasi dan komplek hiburan. 
4) Daya arik wisata minat khusus, seperti : berburu, mendaki gunung, gua, industri dan kerajinan, tempat perbelanjaan, sungai air deras, tempat-tempat ibadah, tempat ziarah dan lain-lain.

Indonesia mempunyai banyak tempat wisata alam yang indah sebagai negarayang lokasinya di daerah Tropis. Wisata alam pengunungan, pantai, hutan, flora dan fauna sangat beragam di Indonesia. Tempat wisata alam terindah di Indonesia ini bukan hanya menjadi tujuan wisatawan lokal, namun juga diminati wisatawan mancanegara. Hampir setiap pulau di Indonesia dianugrahi Tuhan dengan tempat-tempat alam yang indah.

Daya tari wisata dapat berupa potensi alam, yaitu atraksi yang disediakan oleh alam seperti gunung, danau, sungai, pantai, laut, atau potensi budaya yaitu obyek budaya seperti adat-istiadat,

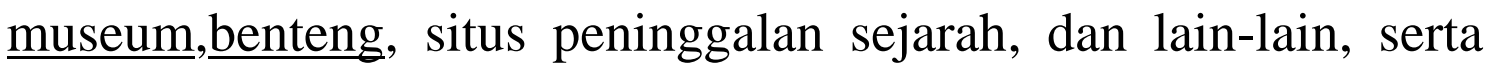
potensi buatan manusia. Ada lagi satu yang sering dimasukan sebagai atraksi wisata yaitu Syaujana atau bentang alam, adalah objek alam atau budaya atau buatan manusia yang dilator belakangi oleh pemandangan alam, seperti Pura Tanah Lot dengan latar belakang pemandangan laut, Pura Batukaru dengan latar belakang Gunung Batukaru, atau hamparan persawahan Jatiluwih dengan latar belakang pemandangan pegunungan di belakangannya. Desa menawarkan suasana perdesaan, yang dapat dikembangkan untuk 
mengantisipasi perkembangan pasar (wisatawan) yang lebih tersegmentasi seiring dengan perkembangan motivasi, ekspektasi dan preferensi pasar yang semakin kompleks berpengalaman dan peka terhadap pelestarian alam, budaya serta golongan minoritas (Smith, 1989).

Konsep penggalian komponen produk desa wisata (atraksi, aksesibilitas, amenitas dan ansilari) semestinya didasarkan pada pengembangan interaksi sosial budaya dari manusia ke manusia (masyarakat desa adat dengan wisatawan) dan dari manusia ke lingkungan. Bentuk interaksi tersebut bertujuan untuk mencapai keutuhan pengalaman tidak hanya bagi wisatawan, melainkan juga masyarakat desa dalam rangka meningkatkan kualitas hidupnya.

Konsep penggalian produk desa wisata berdasarkan pada pengembangan interaksi budaya dari manusia ke manusia dan dari manusia ke alam desa. Manifestasi dari interaksi tersebut bertujuan mencapai keutuhan pengalaman budaya yang total tidak saja bagi wisatawan melainkan juga bagi masyarakat desa (sebagai host atau tuan rumah sebagai subyek yang aktif). 


\section{BAB III}

\section{POTENSI WISATA DESA BONTO UJUNG}

\section{A. Potensi Atraksi Wisata Desa Bonto Ujung}

Atraksi wisata pada umumnya menggunakan sumber daya yang ada seperti lahan, budaya, masyarakat dan alam.Potensi pariwisata Bali memiliki nilai keunggulan pada kolaborasi atau perpaduan antara atraksi wisata alam dan atraksi wisata budaya. Menurut Undang-Undang No. 10 tahun 2009 tentang Kepariwisataan pada Pasal 1 angka 5 menyatakan bahwa atraksi wisata (atraksi wisata) adalah segala sesuatu yang memiliki keunikan, keindahan, dan nilai yang berupa keanekaragaman kekayaan alam, budaya, dan hasil buatan manusia yang menjadi sasaran atau tujuan kunjungan wisatawan. Atraksi wisata memiliki tiga kategori sebagai berikut :

1. Atraksi wisata alam

2. Atraksi wisata budaya

3. Atraksi wisata buatan

B. Atraksi Wisata Alam

Atraksi wisata alam adalah atraksi wisata ciptaan Tuhan Yang Maha Esa yang berwujud sumber daya alam, flora dan fauna, keunikan dan kekhasan ekosistem, budi daya sumber daya alam yang berpotensi serta memiliki atraksi atau atraksi bagi pengunjung 
baik dalam keadaan alami maupun setelah ada usaha budi daya. Sifat dan karakter atraksi wisata alam, yaitu :

1) In Situ. Atraksi wisata alam hanya dapat dinikmati secara utuh dan sempurna di ekosistem atau kawasan atraksi wisata alam tersebut.

2) Perishable. Atraksi wisata alam mudah rusak atau sangat rentan dengan perubahan akibat tangan-tangan manusia yang tidak bertanggungjawab, gejala alam atau bencana alam, dan perubahan cuaca atau iklam.

3) Non Recoverable. Atraksi wisata alam memiliki perilaku pemulihan yang tidak sama, bisa dalam pemulihan jangka waktu pendek dan pemulihan jangka panjang. Pemulihan sebuah atraksi wisata dapat dilakukan oleh masyarakat atau badan pengelola tetapi idelnya suatu atraksi wisata mengalami pemulihan secara alami. Pemulihan secara alami merupakan salah satu wujud pemulihan jangka panjang, tergantung dari faktor dalam (genotype) dan faktor luar (phenotype).

4) Non Substitutable. Sangat jarang terdapat kesamaan sifat dan karakter di setiap atraksi wisata alam yang ada di dalam suatu kawasan.

Desa Bonto Ujung dapat menerapkan pengembangan potensi pariwisata pada bentang alam daratan tinggi (palteau). Desa Bonto 
Ujung memliki potensi atraksi wisata alam yang dapat dikembangkan pada potensi-potensi sebagai berikut :

1) Pantai Kelapa Ujung (jalan poros Makassar Bantaeng)

\section{Atraksi Wisata Budaya}

Atraksi wisata budaya adalah atraksi atau atraksi wisata yang tercipta dari ide, pola piker dan tingkah laku manusia keseharian atau budaya kehidupan masyarakat setempat, seperti adatistiadat.Kebudayaan atau budaya memiliki dua kategori yaitu kebudayaan kebendaan / berwujud (tangible) dan kebudayaan tak benda / tidak berwujud yaitu (intangible). Pemilahan dua potensi pariwisata budaya dalam bentuk tangible dan intangible akan mempermudah masyarakat Desa Bonto Ujung untuk melakukan inventarisasi kebudayaan yang dimiliki. Desa Bonto Ujung memliki potensi atraksi wisata budaya yang dapat dikembangkan pada potensi-potensi sebagai berikut :

1. Kesenian ukir dan kerajinan tangan yang dijual ke Desa

2. Mapacing

\section{Atraksi Wisata Buatan}

Daya wisata buatan adalah atraksi atau atraksi hasil karya manusia yang berwujud museum, peninggalan sejarah, seni dan budaya, wisata agro, wisata buru, wisata petualangan alam, taman rekreasi dan komplek hiburan. Atraksi wisata buatan cenderung akan membawa gagasan atau ide-ide baru, inovasi-inovasi baru 
yang menciptakan pengalaman tersendiri bagi wisatawan. Potensi alam yang kuat dan lahan yang dimanfaatkan sebagai perkebunan atau pertanian dapat memberikan atraksi wisata buatan. Produkproduk yang dihasil dari perkebunan atau pertanian masyarakat setempat dapat dikemas lagi menjadi sebuah produk hasil olahan yang dijual baik secara grosir atau retail seperti terciptanya agrowisata, taman bunga dan kreasi hand bouquet dan ecotourism (ekowisata). Desa Bonto Ujung mampu mengkolaborasikan atraksi alam dan buatan untuk menjadi unsur dari potensi atraksi wisata buatan yang dapat dikembangkan sebagai berikut :

1) Adanya jalur-jalur trekking yang dikembangkan untuk menikmati suasana alam dan kebudayaan masyarakat Desa Bonto Ujung.

2) Adanya jalur-jalur Cycling Tour untuk menikmati keindahan alam melalui jalan-jalan utama dan jalur setapak di Desa Bonto Ujung.

3) Program Pembelajaran(lessong program) seperti art cultural lesson, farm lesson, cooking lesson and mejejahitan lessong.

4) Program yang memacu keterampilan dan ketangkasan seperti traditional game program village tour program dan outing program

5) Pembuatan yoga center atau program senam seperti senam aerobic 


\section{BAB IV}

\section{PANDUAN TATAKELOLA DESA WISATA BONTO UJUNG}

Perumusan tentang tatakelola Desa Wisata Bonto Ujung dalam buku panduan ini didasarkan atas identifikasi permasalahan yang menjadi kendala dalam pengembangan Desa Wisata Bonto Ujung, melalui kegiatan diskusi kelompok terfokus (Focus Group Discussion, FGD) pada tanggal 29 September 2021 di Kantor Desa Bonto Ujung, yang dihadiri para pemangku kepentingan Desa Wisata Bonto Ujung, seperti kades, sekdes, tokoh-tokoh masyarakat, dan warga desa yang bekerja di luar desa

Panduan tentang tatakelola Desa Wisata Bonto Ujung esensinya adalah sekumpulan solusi dari masalah yang menjadi kendala perkembangan Desa Wisata Bonto Ujung dalam bentuk kebijakan solusi ini masih bersifat umum dalam berupa kebijakan dan program yang kelak harus dijabarkan menjadi rencana aksi (action plan) oleh para pemangku kepentingan pariwisata Desa Bonto Ujung dan Pemerintah Kabupaten Jeneponto.Adapun tata kelola yang dapat diimplementasikan untuk memajukan Desa Wisata Bonto Ujung adalah sebagai berikut :

\section{A. PerbaikanAksesibilitas}


Potensi yang dimiliki sebuah Desa Wisata tidak akan mampu menjadi magnet penarik kunjungan wisatawan bila desa tersebut tidak memiliki aksesibilitas yang baik. Desa Wisata harus memiliki aksesibilitas yang baik untuk mempermudah wisatawan menuju Desa Wisata tersebut. Desa Wisata yang berada pada daerah yang sulit dijangkau dan terisolasi, misalnya, akan sulit berkembang dibandingkan dengan desa yang mempunyai akses yang lebih baik.

1. Akses jalan raya

Fasilitas infrastruktur jalan yang menuju Desa Bonto Ujung sudah memenuhi standar jalan raya yang diperuntukan untuk jalur pariwisata (hot mixed), sehingga berbagai tipe kendaraan dapat mengakses jalan tersebut. Hanya saja kendalanya adalah dari untuk akses jalan yang menuju Dusun dusun Desa Bonto Ujung belum ada pemetaan .Kondisi ini sering dikeluhkan oleh para sopir yang kerap mengantar wisatawan mancanegara berkunjung menggunakan bus-bus. Ketika berlangsung diskusi kelompok terfokus pada tanggal 29 September 2021 di kantor Desa Bonto Ujung, para pemuka atau tokoh masyarakat juga mengeluhkan masalah minimnya promosi bahkan peserta diskusi sepakat mengatakan bahwa tidak berkembangnya Desa Bonto Ujung menjadi daerah tujuan Wisata ditengarai karena desa belum ditata dan dikelola secara baik . Hal ini bisa diatasi 
dengan membuat master plant desa yang lebih baik khusunya Pantai Kelapa Bonto Ujung ini sudah pasti akan memudahkan pengembangan dan tata kelola Desa Bonto Ujung yang lebih baik . Desa Wisata Bonto Ujung harus mampu menempatkan eksistensinya di dalam mengembangkan obyek wisata Pantai Kelapa Ujung dengan model pengembangan pembinaan dan pemasaran yang terintegrasi serta menerpakan model pemasaran yang sesuai.

\section{B. Pembentukan Kelembagaan}

Pembentukan dan penguatan kelembagaan sangat diperlukan di dalam pengembangan suatu destinasi wisata secara profesional. Diperlukan pemilahan tugas dan kewenangan dari penyelenggaran suatu destinasi wisata yang memiliki unsur kelembagaan masyarakat. Profesionalitas di dalam sebuah kelembagaan menuntut diterapkannya Standard Operating Procedures (SOP), yaitu serangkaian instruksi kerja tertulis yang dibakukan (terdokumentasi) mengenai proses penyelenggaraan administrasi sebuah Desa Wisata, bagaimana dan kapan harus dilakukan, dimana dan oleh siapa dilakukan.

Pengembangan suatu destinasi menjadi destinasi wisata atau desa menjadi desa wisata, seperti terbentuknya Desa Bonto Ujung menjadi Desa Wisata Rintisan yang kelak akan berkembang, yang sampai saat ini dirasakan belum ada oleh 
masyarakat setempat, memerlukan pembentukan desa wisata serta kelembagaan yang baik, sebagai pengelola hal-hal yang berkaitan dengan pariwisata. Jika kelembagaan yang diperlukan belum ada, maka perlu dibentuk kelembagaan tersebut.Namun jika kelembahaan yang diperlukan sudah ada, maka kelembagaan tersebut perlu dikelola secara baik oleh orangorang setempat yang kompeten agar kepariwisataan berlangsung secara baik, dan menghindari konflik kepentingan antar beberapa pihak.

Berdasarkan diskusi kelompok terfokus dengan tokoh-tokoh masyarakat Desa Bonto Ujung dan pemangku kepentingan pariwisata Desa Bonto Ujung, terungkap bahwa memang belum terbentuk desa wisata serta kelembagaan-kelembagaan yang diperlukan untuk berlangsungnya kepariwisataan di Desa Bonto Ujung.Walaupun bebrapa lembaga pernah ada, karena tidak dikelola dengan baik oleh orang-orang yang kompeten, maka lembaga tersebut sekarang sudah bubar atau hilang. Jenis tata kelola kelembagaan yang diperlukan untuk dapat terselenggaranya kepariwisataan di Desa Bonto Ujung antara lain:

1. Pemberdayaan Kelembagaan Desa Adat

Pada kelembagaan Desa Wisata Bonto Ujung, kelompok masyarakat adat sangat berperan penting.Lembaga 
masyarakat adat merupakan elit kepemimpinan desa yang menjalankan dan menyelenggarakan fungsi adat istiadat dan menjadi bagian dari susunan asli Desa yang tumbuh dan berkembang atas prakarsa masyarakat Desa dengan pucuk kepemimpinan yang dipegang oleh pemuka Adat. Kelembagaan Badan Pengelola Desa Wisata Bonto Ujung dan POKDARWIS akan bertanggungjawab penuh kepada Kelembagaan Masyarakat Adat dalam melaksanakan tugastugas yang sudah diatur dalam Standard Operating Procedures (SOP). Kelembagaan Masyarakat Adat akan mengawasi dan melakukan teguran apabila Kelembagaan Badan Pengelola Desa Wisata Bonto Ujung dan POKDARWIS tidak berjalan sesuai dengan Standard Operating Procedures SOP yang sudah ditetapkan.

Tata kelola kelembagaan harus didukung dengan regulasi berupa peraturan perundang-undangan desa atau dikenal dengan sebutan Perdes. Kelembagaan Masyarakat Adat mengeluarkan kebijakan dalam bentuk Perdes yang khusus mengatur tentang pengembangan dan pengelolaan Desa Wisata Bonto Ujung. POKDARWIS dan Badan Pengelola Desa Wisata Bonto Ujung untuk tetap berjalan dengan selaras untuk kelanggengan Desa Wisata Bonto Ujung.Sebuah Desa Wisata Bonto Ujung juga harus 
didaftarkan secara administratif di kelembagaan pemerintah agar memiliki kekuatan hukum tetap di mata hukum Indonesia. Pendaftaran ini akan menjamin kelancaran operasional Desa Wisata Bonto Ujung karena sudah mengantongi Izin Tetap Usaha Pariwisata (ITUP) dan Tanda Daftar Usaha Pariwisata (TDUP). Hukum adat atau yang lebih dikenal dengan POKDARWIS dan Badan

Pengelola Desa Wisata Bonto Ujung untuk tetap berjalan dengan selaras untuk kelanggengan Desa Wisata Bonto Ujung. Sebagian besar Lembaga Masyarakat Adat memiliki power yang lebih kuat dari Kelembagaan POKDARWIS dan Badan Pengelola Desa Wisata Bonto Ujung dalam menentukan kebijakan dalam pengembangan Desa Wisata Bonto Ujung. Hal yang perlu ditekankan dalam kata " kekuatan" di dalam kalimat di atas adalah bukan elitelit yang duduk dalam Lembaga Masyarakat, tetapi kebijakan yang lahir dari suara masyarakat Desa Bonto Ujung dan diselenggarakan di dalam sebuah pertemuan resmi atau di dalam

2. Pembentukan Kelompok Sadar Wisata (Pokdarwis)

Kelompok Sadar Wisata atau disingkat Pokdarwis merupakan kelompok swadaya dan swakarsa yang tumbuh dari, oleh dan untuk masyarakat serta bertujuan untuk 
meningkatkan pengembangan pariwisata daerah dan mensukseskan pembangunan pariwisata nasional. Dengan demikian kelompok sadar wisata merupakan kelompok yang tumbuh atas inisiatif dan kemauan serta kesadaran masyarakat sendiri guna ikut berpartisipasi aktif memelihara dan melestarikan berbagai obyek dan atraksi wisata dalam rangka meningkatkan pembangunan kepariwisataan di daerah.

Pembangunan kepariwisataan nasional, regional dan lokal diarahkan kepada peningkatan peran pariwisata menjadi sektor andalan yang mampu membangkitkan aktivitas ekonomi sektor -sektor lain yang terkait langsung dan tidak langsung dengan pariwisata, sehingga mampu memperluas lapangan kerja, meningkatkan pendapatan masyarakat, pendapatan daerah dan negaraserta penerimaan devisa. Pembangunan kepariwisataan merupakan kegiatan lintas sektoral, karena itu suksesnya pembangunan kepariwisataan nasional dan regional sangat ditentukan oleh adanya dukungan serta partisipasi aktif seluruh lapisan masyarakat, baik unsurpemerintah, pihak swasta maupun masyarakat lainnya.

Harus disadari dan disyukuri oleh semua pihak, terutama oleh masyarakat Desa Bonto Ujung bahwa 
sesungguhnya Desa Bonto Ujung memiliki potensi kekayaan alam dan budaya yang melimpah yang dapat dijadikan obyek dan atraksi wisata, baik wisata alam, budaya maupun wisata religi. Desa yang indah semua itu dapat dijadikan sebagi obyek wisata alam. Demikian pula kekayaan budaya yang berupa adat-istiadat, kesenian, sejarah, dan budaya hidup masyarakat serta berbagai keterampilan yang dimiliki masyarakatnya untuk membuat kerajinan tangan dan industri rumah tangga lainnya dapat juga dijadikan sebagai atraksi wisata budaya. Berbagai peninggalan sejarah Desa Bonto Ujung, dan adanya kegiatan memperbaiki perahu dan jala merupakan atraksi wisata yang tiada ternilai harganya, baik bagi masyarakat/wisatawan lokal, nasional maupun mancanegara. Oleh sebab itu kekayaan alam dan budaya tersebut, di samping harus dieksplorasi dan dimanfaatkan secara optimal untuk memajukan dan mensejahterakan masyarakat Desa Bonto Ujung juga harus dijaga, dipelihara, dirawat dan dilestarikan keberadaannya. Oleh karena itu, semua lapisan masyarakat harus berpartisipasi aktif dan melibatkan diri baik langsung maupun tidak langsung untuk memeliharadan melestarikan kekayaan alam dan budaya yang dimilikinya. 
Berkaitan dengan hal tersebut, dibutuhkan kelompokkelompok yang tumbuh dari, oleh danuntuk masyarakat itu sendiri, yang peduli akan keberadaan dan pelestarian kekayaan alam dan budaya yang dimiliki masyarakat Desa Bonto Ujung. Untuk itu diperlukan sumber informasi yang memadai sebagai acuan dan pegangan dalam membentuk kelompok-kelompok yang dimaksud.Kelompok-kelompok yang tumbuh dari, oleh dan untuk masyarakat dalam memelihara, menjaga dan melestarikan kekayaan alam dan budaya inilah yang disebut dengan Kelompok Sadar Wisata atau disingkat Pokdarwis.

Kelembagaan Pokdarwis. adalah garda terdepan Desa Wisata Bonto Ujung untuk membantu masyarakat Desa Wisata Bonto Ujung mengembangkan Desa Wisata Bonto Ujung dan menanamkan pemahaman tentang pengelolaan dan pengembangan Desa Wisata Bonto Ujung. Secara umum, fungsi Pokdarwis. dalam kegiatan kepariwisataan adalah:

1) Sebagai penggerak Sadar Wisata dan Sapta Pesona di lingkungan wilayah di destinasi wisata.

2) Sebagai Mitra Pemerintah dan pemerintah daerah (kabupaten/ kota) dalam upaya perwujudan dan pengembangan Sadar Wisata di daerah. 
Pokdarwis. berkedudukan di Desa Wisata Bonto Ujung yang sedang dikembangkan.Pemilihan anggota Pokdarwis. bersifat sukarela, mereka yang tergabung di dalam Pokdarwis. memiliki dedikasi, komitmen dalam pengembangan kepariwisataan. Anggota Pokdarwis. adalah masyarakat yang bertempat tinggal di Desa Wisata Bonto Ujung dan memiliki pengalaman dibidang kepariwisataan baik secara langsung maupun tidak langsung. Besaran jumlah organisasi Pokdarwis. minimal 15 orang.( Kepengurusan Pokdarwis terdiri dari Pembina, Penasehat, Pimpinan, Sekretariat, Anggota, dan seksiseksi (antara lain: Keamanan dan Ketertiban, Kebersihan dan Keindahan, Atraksi Wisata dan Kenangan, Hubungan Masyarakat dan Pengembangan Sumber Daya Manusia, Pengembangan Usaha)(Gambar 4.1) 


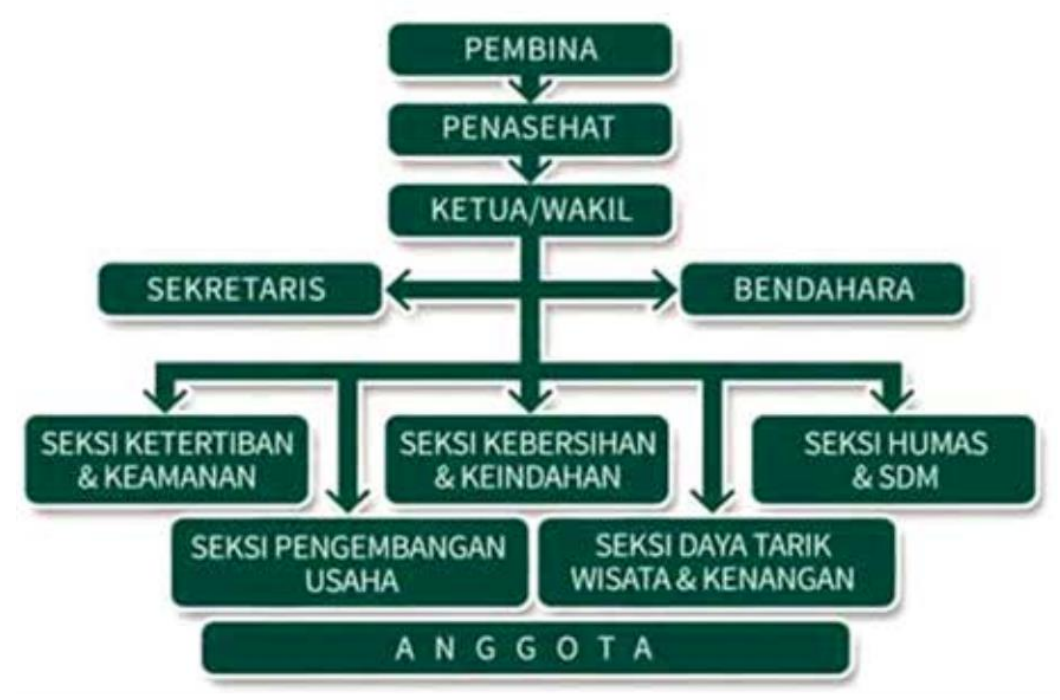

Gambar. 4.1

Struktur Organisasi Kelompok Sadar Wisata

3. Pembentukan Badan Pengelola Desa Wisata Bonto Ujung

Dari pengalaman sejarah beberapa destinasi wisata yang sudah berkembang yang memang tidak memiliki badan pengelola pariwisata, kerap terjadi konflik-konlik kepentingan antara kelompok masyarakat dan pemangku kepentingan pariwisata.Hal ini karena tiadanya lembaga dengan personilnya yang mengatur perkembangan pariwisata dan mengharmonikan kepentingan beberapa kelompok masyarakat.

Belajar dari pengalaman destinasi wisata yang tidak memiliki badan pengelola pariwisata, dan sesuai rencana pengembangan Desa Wisata serta mengantisipasi terjadinya konflik kepentingan antara beberapa kelompok masyarakat, 
maka perlu dibentuk "Badan Pengelola Desa Wisata Bonto Ujung", yang melibatkan perwakilan dari kelompokkelompok masyarakat dan pemangku kepentingan pariwisata. Penyadaran terhadap kelompok masyarakat yang tidak setuju adanya Badan Pengelola Desa WisataBonto Ujung perlu dilakukan, agar mereka sadar pentingnya keberadaan Badan Pengelola Desa Wisata Bonto Ujung.

Kelembagaan Badan Pengelola Desa Wisata Bonto Ujung adalah sebuah lembaga yang melaksanakan manajemen Desa Wisata Bonto Ujung dengan cara atau sistem manajemen pengelolaan yang profesional. Badan Pengelola Desa Wisata Bonto Ujung mengeluarkan kebijakan-kebijakan yang bersifat managerial dalam pengembangan Desa Wisata Bonto Ujung. Mereka yang bekerja di Badan Pengelola Desa Wisata Bonto Ujung akan digaji sesuai dengan kompetensi mereka masing-masing sesuai dengan struktur kelembagaan yang dianggarkan dalam keuangan Desa Wisata Bonto Ujung. Badan Pengelola Desa Wisata Bonto Ujung direkrut dari kemampuan masyarakat setempat dalam mengelola Desa Wisata Bonto Ujung dengan memprioritaskan peranan masyarakat atau para pemuda yang memiliki latar belakang pendidikan atau keterampilan di bidang pariwisata atau bidang-bidang lain yang dibutuhkan. 
Badan Pegelola Desa Wisata harus memiliki struktur organisasi yang jelas, siapa di devisi manager apa, dan siapa personal tenaga kerja (lihat gambar 4.2).

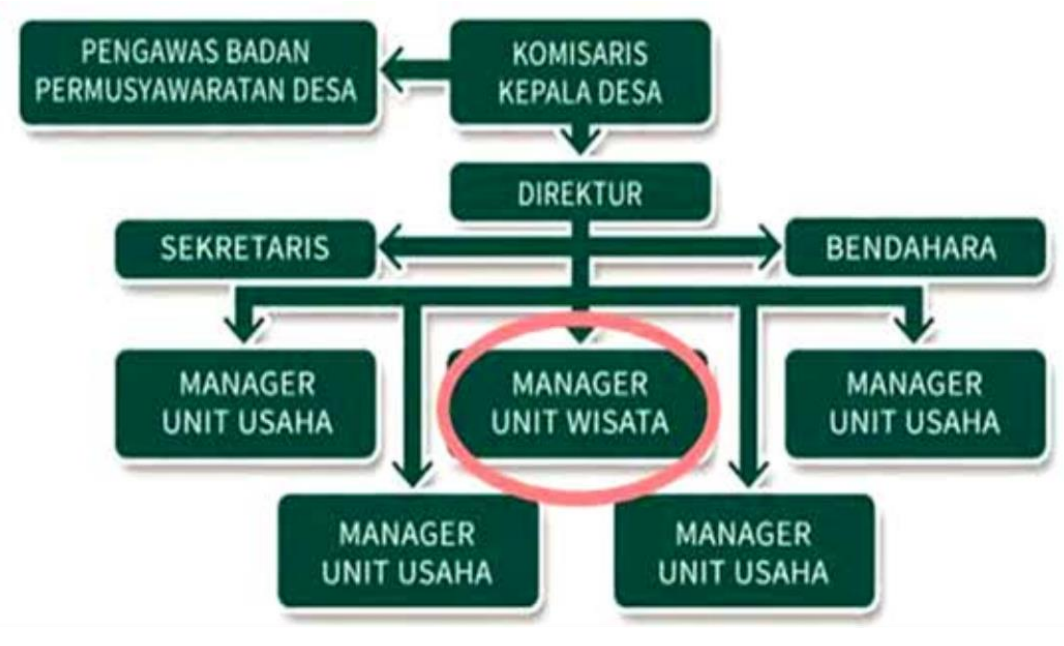

Gambar. 4.2

Struktur organisasi usaha milik desa

Pembentukan Koperasi Wisata

Desa Wisata juga dapat dikelola oleh koperasi, dimana koperasi didirikan Pengusul kepengurusan koperasi oleh sedikitnya oleh 20 anggota yang membentuk kepengurusan koperasi dan dikukuhkan oleh Dinas Koperasi setempat menjadi badan hukum yang berkewajiban mengelola kegiatan dan mendapatkan keuntungan (Sisa Hasil Usaha/SHU) dan dipertanggungjawabkan pada Rapat Anggota Tahunan (RAT) koperasi. Kepengurusan koperasi dapat diperbarui secara periodik atau sesuai dengan usuIan dalam RAT 


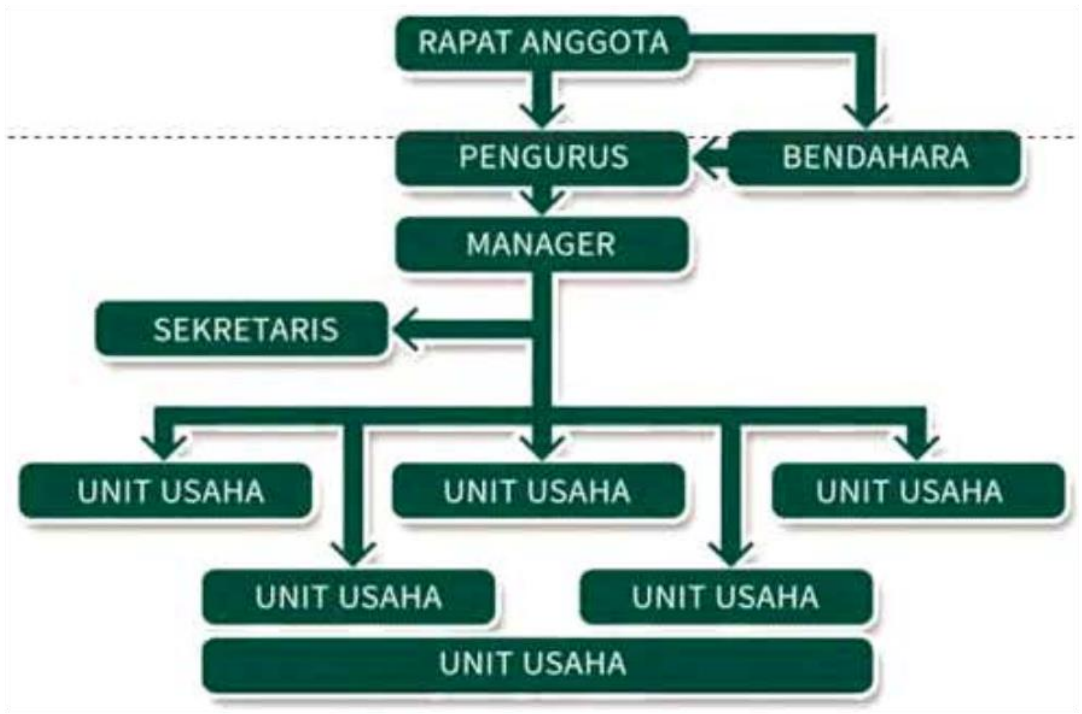

Gambar 4.3

Struktur Organisasi Koperasi Wisata

\section{Pembentukan Kelompok Pemandu Wisata Lokal}

Seluk beluk tentang macam atraksi wisata, keunikan, dan sejarahnya hanya diketahui dengan baik oleh masyarakat setempat yang dalam hal ini adalah masyarakat Desa Bonto Ujung.Jika ada wisatawan nusantara atau mancanegara yang berkunjung ke Desa Bonto Ujung yang dapat menjelaskan dengan baik adalah masyarakat Desa Bonto Ujung.Untuk mengantisipasi peningkatan kunjungan wisatawan ke Desa Wisata Bonto Ujung kelak, maka perlulah dibentuk kelompok pemandu wisata lokal.Kelompok pemandu wisata lokal ini adalah suatu lembaga yang mengorganisasikan dan mengkoordinasikan para pemandu wisata lokal yang bersedia menjadi anggota kelompok pemandu wisata 
lokal. Siapa saja anggota masyarakat yang berniat terjum menjadi pemandu wisata dan merasa

memiliki pengetahuan sejarah dan seluk-beluk atraksi wisata Desa Bonto Ujung dapat menjadi anggota kelompok, tetapi sebelumnya harus dilatih menjadi pemandu wisata, baik menyangkut pengetahuan pariwisata alam, budaya, dan buatan Desa Bonto Ujung, maupun pelatihan bahasa asing yang dianggap perlu. Pelatihan sebaiknya difasilitasi oleh Pemerintah Kabupaten Jeneponto cq Dinas Pariwisata dan Kebudayaan Kabupaten Jeneponto bekerja sama dengan Perhimpunan Pemandu Wisata Indonesia Cabang Bali atau Cabang Jeneponto.

\section{Peningkatan Kualitas Sumber Daya Manusia}

Manusia atau masyarakat merupakan salah satu sumber daya terpenting di dalam penerapan pengembangan pariwisata berbasis masyarakat (community based tourism), termasuk pengembangan Desa Wisata Bonto Ujung. Sumber Daya Manusia yang handal adalah manusia yang memiliki :

1) Kecerdasan otak (Intelektual Quotient disingkat dengan IQ) Kecerdasan IQ adalah memiliki kemampuan untuk menerima, menyimpan, dan mengolah informasi menjadi data dan mahir dalam menggunakan logika untuk menganalisis permasalahan; 
2) Kecerdasan emosional (Emotional Quotient disingkat dengan EQ) IQ perlu diseimbangkan dengan kecerdasan emosional, kecerdasan EQ adalah kemampuan mengenali perasaan sendiri dan perasaan orang lain,kemampuan memotivasi diri sendiri, serta kemampuan mengolah emosi dengan baik pada diri sendiri \& orang lain.

3) Kecerdasan spiritual (Spiritual Quotient disingkat dengan SQ). IQ dan EQ memerlukan kecerdasan spiritual untuk menyeimbangkan kekuatan IQ dan EQ dalam diri. Kecerdasan spiritual adalah kemampuan seseorang untuk mengerti \& menerima makna pada apa yang dihadapi dalam kehidupan, sehingga seseorang akan memiliki arah dalam menghadapi persoalan hidup.

Sumber Daya Manusia (SDM) merupakan tantangan yang cukup berat bagi pengembangan Desa Wisata Bonto Ujung, karena SDM sangat menentukan segala sesuatu yang berhubungan dengan Desa Wisata Bonto Ujung dan pariwisata.Permasalahan SDM yang dijumpai di Desa Wisata Bonto Ujung adalah:

- Pertama, karena memang tingkat keterdidikan yang rendah;

- Kedua, kaum pemuda sebagian besar lebih memilih merantau ke kota, sehingga desa menjadi miskin SDM usia muda dan hanya ditinggali golongan orang tua yang kurang produktif 
- Ketiga, lulusan sarjana atau sekolah menengah sudah memadai namun tidak ada bidang pariwisata, sehingga SDM yang ada kurang cocok untuk mengembangkan Desa Wisata Bonto Ujung.

Berdasarkan pengakuan tokoh-tokoh masyarakat Desa Bonto Ujung ketika dilaksanakan diskusi kelompok terfokus (FGD) terungkap bahwa kualitas dan kuantitas sumber daya manusia (SDM) Desa Bonto Ujung masih rendah, terutama kualitas SDM pendukung pariwisata. Seperti belum adanya kesadaran wisata di kalangan masyarakat, kurangnya keterampilan dan tatakrama melayani tamu yang berkunjung ke Desa Bonto Ujung, kurangnya tatakrama menerima tamu yang akan menginap di rumah-rumah penduduk yang kelak menjadi rumah tinggal wisatawan (homestay), dan lain-lain.

Andaikan ada wisatawan yang berkunjung ke Desa Bonto Ujung, belum ada pemandu wisata lokal yang siap mengantar wisatawan mengunjungi atraksiwisata Desa Bonto Ujung. Seandainya ada wisatawan yang menginap di rumah-rumah penduduk, tuan rumah juga belum siap memberikan pelayanan sewajarnya kepada wisatawan. Solusi dari masalah yang diuraikan sebelumnya adalah perlunya peningkatan kualitas SDM masyarakat Desa Bonto Ujung, baik pemuda/pemudi-nya, para 
penduduk yang kelak rumahnya kelak memenuhi syarat dijadikan homestay atau rumah tinggal tamu.

SDM sebagai pelaku pariwisata mendapat perbedaan perlakuan dengan SDM diluar pelaku pariwisata. SDM diluar pelaku pariwisata akan masuk ke dalam pelaku atraksi wisata seperti petani yang membajak sawah, masyarakat yang melaksanakan kegiatan keagaaman, masyarakat yang melakukan kegiatan kebudayaan dan lain-lain. SDM pelaku pariwisata akan menjadi tenaga kerja yang memberikan jasa hospitality kepada wisatawan, sebagai pengusaha dan badan pengelola yang bekerja dibalik layar yang mengembangkan Desa Wisata tersebut, dan menjadi orang-orang yang duduk di kelembagaan pariwisata terkait Desa Wisata tersebut.

Peningkatan kualitas SDM dapat dilakukan dengan cara memberikan pelatihan yang terkait pariwisata, antara lain:

1. Pelatihan guide local

Guide biro perjalanan hanya boleh mengantarkan wisatawan sampai di Desa Bonto Ujung, dan setelah sampai di Desa Bonto Ujung pengantaran diserahkan kepada guide lokal, karena hanya guide lokalah yang tahu seluk-beluk, sejarah dan budaya masyarakat Desa Bonto Ujung. Untuk itu perlu dilakukan pelatihan menyangkut pengetahuan guide lokal tentang kepariwisataan Desa Bonto Ujung.Pelatihan bisa difasilitasi 
oleh Dinas Pariwisata Kabupaten Jeneponto bekerjasama dengan Perhimpunan Pramuwisata Indonesia Cabang Sulsel atau Cabang Jeneponto.

2. Pelatihan pengembangan keahlian manajemen pengelolaan Desa Wisata dan hospitality.

Pelatihan jenis ini sangat diperlukan oleh masyarakat Desa, agar mereka tahu menyangkut manajemen pengelolaan suatu Desa Wisata.

3. Pelatihan pengolahan kuliner lokal

Pelatihan pengolahan kuliner lokal sangat penting, karena ketika ada wisatawan berkunjung atau membeli paket wisata Desa Bonto Ujung, maka harus disuguhkan menu khas Desa Bonto Ujung sebagai keunikan Desa Wisata Bonto Ujung, yang berbeda dengan Desa Wisata lain.

4. Pelatihan menjadi wirausaha pariwisata perdesaan

Generasi muda sebagai SDM Desa Wisata Bonto Ujung hendaknya dilatih untuk menjadi wirausaha pariwisata perdesaan seperti pembuatan kelompok usaha lokal, dan memberikan kesempatan pada masyarakat setempat untuk ikut mengendalikan usaha pariwisata yang dapat dikembangkan di Desa Wisata Bonto Ujung dan menciptakan regenerasi pariwisata. 
Target utama peningkatan kualitas SDM masyarakat Desa Wisata Bonto Ujung adalah agar masyarakat desa Bonto Ujung mampu membuat perencanaan desa wisata secara mandiri. Artinya, masyarakat agar bisa mengorgnisir diri dan mampu menjadi subyek dalam setiap pengambilan keputusan, khususnya yang terkait dengan program pengembangan desa wisata di Desa Bonto Ujung

\section{Peningkatan Promosi}

Promosi merupakan kegiatan untuk memperkenalkan produk, meyakinkan dan meningkatkan produk, dan mengingatkan kembali produk sasaran pembeli dengan harapan mereka tergerak hatinya dan secara sukarela membeli produk.Sasaran dari promosi pariwisata adalah calon wisatawan (sebagai calon konsumen).Promosi pariwisata dikatakan berhasil dan efektif apabila mampu mendapatkan calon wisatawan yang membeli produk/paket wisata yang ditawarkan.Packaging atau pengemasan produk wisata sangat menentukan kesuksesan promosi Desa Wisata Bonto Ujung. Packaging atau pengemasan yang baik dan mampu menunjukkan nilai pembeda serta keunikan Desa Wisata dari Desa Wisata lainnya yang ada di Jeneponto maka dapat mempermudah jalur promosi Desa Wisata. 
Penentuan pasar dalam melakukan promosi sangat penting untuk dikaji terlebih dahulu.Wisatawan memiliki tipologi atau motivasi yang berbeda-beda dalam pemilihan atraksi wisata.Perlu adanya pemahaman persepsi wisatawan terdahap Desa Wisata Bonto Ujung agar promosi Desa Wisata Bonto Ujung tidak salah sasaran. Promosi yang dapat ditempuh sebuah Desa Wisata Bonto Ujung adalah sebagai berikut :

1. Promosi melalui Pemerintah Pusat

Desa Wisata Bonto Ujung mengajukan permohonan kepada Pemerintah Pusat melalui Kementrian Pariwisata sesuai kewenangan struktural kelembagaan negara agar Desa Wisata Bonto Ujung dapat masuk ke dalam kalender pariwisata Nasional dan dalam event-event pariwisata di Republik Indonesia.

2. Promosi melalui Pemerintah Daerah Provinsi dan Kabupaten/Kota Desa Wisata Bonto Ujung mengajukan permohonan kepada Pemerintah Daerah melalui Dinas Pariwisata untuk dapat dipromosikan sebagai salah satu atraksi wisata unggulan yang dimiliki Pemerintah Daerah.Pemerintah Daerah sesuai dengan adanya pembagian urusan pemerintahan antara pusat dan daerah serta berlakunya desentralisasi pemerintahan dan asas otonomi daerah dapat mempromosikan Desa Wisata Bonto Ujung 
kedalam promosi pariwisata Pemerintah Daerah yang dipromosikan baik dalam dan luar negeri.

3. Promosi melalui website atau media social

Desa Wisata Bonto Ujung dapat membuat dan mengelola website secara independen dan membuat beberapa accountaccount media sosial yang sedang menjadi trend di kalangan masyarakat dunia untuk dapat mempromosikan pariwisata secara tidak langsung.Website dan media sosial pada beberapa tahun belakangan ini memiliki kemampuan yang cukup pesat dan memiliki posisi yang kuat dalam mempromosikan atraksi wisata kepada calon wisatawan.Wisatawan dapat mencari melakukan akses terhadap informasi Desa Wisata Bonto Ujung dimanapun dan kapanpun, sehingga dapat lebih mudah meyakinkan calon wisatawan tanpa harus bertemu langsung dengan calon wisatawan.

4. Promosi melalui biro perjalanan wisata Desa Wisata Bonto Ujung dapat menjalin kerjasama dengan Biro Perjalanan Wisata atau Travel Agent dalam mempromosikan Desa Wisata Bonto Ujung. Travel Agent akan menjadikan Desa Wisata Bonto Ujung sebagai salah satu tempat yang akan dikunjungi dalam Pakert Perjalanan Wisata yang dibuat oleh Travel Agent. Kerjasama ini diikat 
dengan sebuah kontrak kerjasama dan masing-masing pihak memperoleh hasil yang bernilai ekonomi.

5. Promosi melalui iklan

Iklan atau advertising adalah bentuk komunikasi tidak langsung yang dilakukan oleh Badan Pengelola Desa Wisata Bonto Ujung dengan calon wisatawan yang tertarik terhadap produk atau paket Desa Wisata Bonto Ujung.Desa Wisata Bonto Ujung harus membuka jalur untuk menjalin kerjasama dengan media lokal, media nasional dan media internasional untuk promosi baik secara visual maupun cetak.Kekuatan iklan dalam promosi pariwisata sangat kuat, iklan dapat dengan cepat mempengaruhi wisatawan baik dari permainan kata-kata dalam media cetak atau keunikan iklan secara visual.Pemasangan billboard di persimpangan jalan atau akses jalur transportasi yang padat dapat menjadi pertimbangan Badan Pengelola Desa Wisata Bonto Ujung.

Prinsip promosi pariwisata yang baik adalah kejujuran (honesty) dan kepercayaan (trust).Sebuah paket atau produk Desa Wisata yang ditawarkan kepada wisatawan haruslah sesuai dengan yang ada di lapangan. Terkadang demi memperoleh angka kunjungan atau jumlah wisatawan yang tinggi, Desa Wisata tidak jujur dalam mempromosikan paket / produk yang mereka miliki. Desa Wisata harus menerapkan 
kepercayaan dan kejujuran untuk meraih wisatawan repeater. Wisatawan repeaterakan memberikan testimoni yang baik untuk Desa Wisata, sehingga mampu membantu promosi secara tidak langsung yang lebih meyakinkan bagi caloncalon wisatawan lainnya. Apabila terjadi pembohongan publik terhadap paket/produk wisata yang ditawarkan maka Desa Wisata hanya akan meraih wisatawan first timer. Wisatawan first timer akan kecewa dan memberikan testimoni buruk mengenai Desa Wisata dan akan berpengaruh terhadap keberlanjutan Desa Wisata.

\section{E. Penataan Wajah Desa}

Wajah Desa Wisata Bonto Ujung sangat berpengaruh terhadap Kesan pertama wisatawan ketika memasuki Desa Bonto Ujung. Wajah Desa Wisata Bonto Ujung merupakan tampilan awal yang mampu menarik perhatian wisatawan. Struktur Desa Wisata Bonto Ujung yang dibiarkan alami akan menambah nilai keunikan sebagai nilai lebih bagi wisatawan. Penataan adalah upaya dinamis untuk menjaga dan memelihara potensi dan sumber daya wisata dalam penyesuaian fungsi ruang dan waktu yang tidak bertentangan dengan prinsip pelestarian dalam penerapan prinsip kelayakan ekonomi, kesehatan lingkungan, keadilan sosial dan kemasyarakatan. Penataan wajah Desa Wisata Bonto 
Ujung dapat dimulai dari susunan mikro yaitu susunansusunan rumah masyarakat setempat, setelah itu beranjak kepada susunan semi - makro yaitu susunan lingkungan Desa, dan terakhir susunan makro yaitu keseluruhan penataan desa dari rumah tinggal, lingkungan Desa, lahan perkebunan, lahan persawahan aset-aset alam dan lain-lain.

1) Penataan wajah Desa Wisata Bonto Ujung pada susunan mikro, yaitu penataan rumah masyarakat Desa Wisata Bonto Ujung dengan mempertahankan keaslian bangunan rumah atau struktur rumah dengan tata ruang atau tata letak rumah tradisional, perlu adanya peremajaan bangunan untuk mengatasi kerapuhan dari rumah-rumah tradisional. Desa Wisata Bonto Ujung sebagian besar identik dengan eksistensi sebuah desa yang memiliki filsafat - filsafat di dalamnya. Tata ruang atau tata letak rumah tradisional yang berada di Desa Wisata Bonto Ujung memiliki bentuk keterkaitan dengan unsur-unsur filosofi kehidupan masyarakat.

2) Penataan wajah Desa Wisata Bonto Ujung pada susunan semi - makro,yaitu menjaga keasrian wilayah sisi terluar bangunan rumah yaitu lingkungan sekitar Desa Wisata Bonto Ujung. Pemilihan tanaman dalam lingkup eksterior harus dengan sentuhan tanaman-taman khas Desa Wisata 
Bonto Ujung, sehingga dari tanaman khas dapat diambil sebagai simbol atau logo dari Desa Wisata Bonto Ujung tersebut seperti contohnya mengambil Bunga Cempaka sebagai simbol Desa Wisata Desa Wisata Bonto Ujung cenderung mengembangkan ecotourism atau ekowisata yang mampu menciptakan pariwisata berkelanjutan. Desa Wisata Bonto Ujung bersifat ramah lingkungan dan lebih mengedepankan pelestarian lingkungan hidup untuk lingkungan Desa Wisata Bonto Ujung.

3) Penataan wajah Desa Wisata Bonto Ujung pada susunan makro,yaitu penataan wajah Desa Wisata Bonto Ujung dengan Perencanaan yang membagi Desa Wisata Bonto Ujung menjadi perwilayahan yang disebut dengan zona. Desa Wisata Bonto Ujung idealnya terbagi dari beberapa zona yaitu:

1) Zona Konservasi Rumah Penduduk

Zona yang melindungi rumah penduduk sebagai aset kebudayaan Desa Wisata Bonto Ujung dan sebagai basis pengembangan home industry;

2) Zona Pengembangan

Zona yang diperuntukkan untuk pusat kegiatan Desa Wisata Bonto Ujung seperti atraksi wisata dan sebagainya yang memiliki atau mempunyai potensi 
sebagai point of view dan sebagai pintu utama untuk masuk ke Desa Wisata Bonto Ujung;

3) Zona Komersial

Zona yang diperuntukkan untuk pengembangan usaha penyediaan akomodasi homestay untuk tempat tinggal wisatawan yang ingin menginap di Desa Wisata Bonto Ujung;

4) Zona Transisi

Zona yang diperuntukkan sebagai lahan terbuka untuk mengembangkan atraksi wisata buatan seperti agrowisata dan pengembangan teknologi ramah lingkungan seperti pembangkit listrik tenaga matahari/surya, biogas dan lain-lain.

\section{F. Pengadaan Akomodasi}

Desa Wisata Bonto Ujung sebaiknya dilengkapi dengan ausaha pariwisata, dan akomodasi merupakan bagian dari usaha pariwisata yang disebut sebagai usaha penyediaan akomodasi.Usaha Penyediaan Akomodasi adalah usaha penyediaaan pelayanan penginapan untuk wisatawan yang dapat dilengkapi dengan pelayanan pariwisata lainnya.Pengadaan akomodasi memiliki peran penting dimana akomodasi sebagai tempat tinggal wisatawan yang ingin tinggal dan menikmati kehidupan di Desa Wisata Bonto 
Ujung. Pengadaan akomodasi dilakukan oleh masyarakat setempat dengan cara:

1. Menjadikan dan menata tempat tinggal masyarakat sebagai tempat menginap yang layak untuk wisatawan (homestay)

2. Memberikan ruang khusus bagi wisatawan untuk melakukan aktivitas atau ruang privat;

3. Menyediakan fasilitas yang memadai untuk wisatawan, seperti ruangan kamar tidur yang bersih, tempat tidur yang bersih, sanitasi yang baik dan bersih, pemberian fasilitas sarapan untuk wisatawan dan lain-lain sesuai dengan standar akomodasi; Pondok Wisata adalah penyediaan akomodasi berupa bangunan rumah tinggal yang dihuni oleh pemiliknya dan dimanfaatkan sebagian untuk disewakan dengan memberikan kesempatan kepada wisatawan untuk berinteraksi dalam kehidupan sehari-hari pemiliknya.

Pondok wisata merupakan sebuah wadah yang berupa unit hunian sebagai pendukung bagi kawasan/kompleks sekitar wisata yang berbentuk pondok penginapan. Pondok wisata merupakan bentuk dari implementasi community base tourism yang berpihak kepada masyarakat lokal. Standar Usaha Pondok Wisata adalah 
rumusan kualifikasi Usaha Pondok Wisata dan/atau klasifikasi Usaha Pondok Wisata yang mencakup aspek produk, pelayanan dan pengelolaan Usaha Pondok Wisata.Kepemilikan usaha pondok wisata merupakan usaha perseorangan yang diprioritaskan kepemilikannya dimiliki oleh masyarakat setempat. Pengadaan akomodasi akan memberikan lapangan kerja bagi masyarakat lainnya.

Pondok Wisata juga dimungkinkan dibangun diluar dari rumah-rumah masyarakat setampat atau tidak memanfaatkan rumah masyarakat setempat. Pembangunan pondok wisata dibangun pada zona komersial Desa Wisata Bonto Ujung. Pemisahan ini dilakukan untuk menjaga kelestarian rumah-rumah tradisional di Desa Wisata Bonto Ujung.Bangunan pondok wisata yang berada di luar rumah penduduk atau sengaja dibuat dengan tidak memanfaatkan rumahrumah masyarakat setempat harus mengadopsi arsitektur tradisional masyarakat setempat. Adopsi ini dilakukan untuk menjaga kebudayaan dan memberikan pengalaman bagi wisatawan menginap di bangunan tradisional, tetapi dengan fasilitas standar internasional (untuk kenyamanan wisatawan). 


\section{G. Peningkatan Kesadaran Warga}

Kesadaran adalah sebuah pemahaman yang lahir dari diri manusia untuk berpikir jernih dalam menyikapi suatu hal atau suatu masalah dengan pemahaman dan logika berpikir.Masyarakat harus menyadari dan mampu membaca peluang usaha pariwisata di Desa Wisata Bonto Ujung tersebut.Masyarakat juga harus menyadari bahwa pariwisata yang berkembang di Desa Wisata Bonto Ujung harus dikendalikan dengan adanya partisipasi masyarakat secara totalitas. Investor atau orang yang berada di luar Desa Wisata Bonto Ujung seperti pengembang dan lain sebagainya tidak akan mampu memahami sebatas mana keperluan, kapasitas dan kelayakan pengembangan pariwisata. Mereka hanya akan berpikir bagaimana menambah kuota pembangunan untuk mendatangkan pendapatan yang berlipat-lipat. Semua ini berbeda dengan sikap masyarakat setempat, mereka akan berusaha menjaga tempat tinggal mereka agar tetap utuh seperti apa adanya dan berusaha untuk selalu memegang teguh aturan-aturan adat yang berlaku untuk keberlanjutan.

Selama ini pengembangan pariwisata berbasis masyarakat menggunakan pendekatan community based tourism, dimana masyarakat mempunyai peran yang sangat penting dalam 
menunjang pembangunan pariwisata. Peningkatan kesadaran dapat dilakukan dengan cara-cara sebagai berikut :

1. Membangkitkan Kesasaran (Awareness). Ilmu komunikasi membantu masyarakat dalam memahami bagaimana masyarakat mampu untuk sadar (aware) terhadap terhadap lingkungan dan pariwisata. Keterlambatan dan lupa membangkitkan kesadaran pariwisata membuat masyarakat bertindak arogan dan memberikan dampak negatif terhadap Desa Wisata Bonto Ujung. Desa Wisata Bonto Ujung akan dieksploitasi dengan pembangunan-pembangunan yang tidak terkendali dan mengalami masa stagnasi dimana Desa Wisata Bonto Ujung kehilangan jati diri dan ditinggalkan wisatawan. Komunikasi yang baik akan membawa masyarakat kedalam kesadaran terdalam bahwa menjaga Desa Wisata Bonto Ujung tetap utuh dan lestari akan memberikan dampak positif yaitu pariwisata berkelanjutan.

2. Penyuluhan pariwisata berbasis masyarakat Penyulunan pariwisata berbasis masyarakat dimaksudkan memberikan motivasi dan penanaman pemahaman sadar wisata kepada masyarakatDesa Wisata Bonto Ujung sebagai pelaku utama pariwisata.Penyuluhan diperlukan untuk lebih memahami tentang fenomena pariwisata, potensi alam dan budaya sebagai penunjang pariwisata, sekaligus menentukan 
kualitas produk wisata yang ada di Desa Wisata Bonto Ujungnya.

3. Musyawarah Desa

Masyarakat memerlukan wadah untuk difasilitasi sebagai bentuk evaluasi dari pengembangan pariwisata.Musyawarah desa merupakan sebuah wadah yang tepat untuk mengetahui problematika yang terjadi di masyarakat dan tidak tersentuh oleh para elit Desa Wisata Bonto Ujung.Apabila ada pandangan-pandangan negatif yang memicu terjadinya konflik, hal tersebut dapat cepat diketahui dan dapat dilakukan konfirmasi mengenai pandangan-pandangan negatif tersebut.

\section{H. Pengembangan Paket Wisata}

Wacana membangun Desa Wisata Bonto Ujung sebanyakbanyaknya membuat sebuah dilema besar di masyarakat. Semua desa berupaya untuk mengembangkan Desa Wisata, tetapi tidak sedikit dari desa-desa tersebut memiliki atraksi wisata yang hampir sama bahkan 100\% memiliki kesamaan. Sejatinya sebuah Desa Wisata, seperti halnya Desa Wisata Bonto Ujung harus menonjolkan perbedaan dari Desa Wisata lainnya sebagai keunikan, tujuannya adalah untuk memberikan nilai pembeda, sehingga mampu menciptakan rasa penasaran dan akhirnya menarik wisatawan untuk berwisata di Desa Wisata Bonto Ujung. 
Langkah-langkah yang harus ditempuh dalam pengembangan paket wisata untuk Desa Wisata Bonto Ujung yaitu :

1. Inventarisasi potensi pariwisata

Masyarakat dan pihak-pihak yang memiliki peranan serta kewenangan dalam pengembangan Desa Wisata Bonto Ujung harus melakukan inventarisasi potensi pariwisata baik potensi alam dan budaya untuk dapat memetakan atraksi wisata yang mampu dikemas untuk ditawarkan kepada wisatawan.

2. Pasar pariwisata

Penentuan segmentasi pasar dalam pengembangan paket wisata akan menghantar Desa Wisata Bonto Ujung menjadi lebih kreatif dalam pengemasan produk/paket Desa Wisata Bonto Ujung. Pada sektor inilah akan muncul ide-ide kratif untuk pengembangan atraksi wisata buatan, dimana atraksi wisata buatan akan menunjang atraksi wisata alam dan atraksi wisata budaya yang sudah ada sebelumnya. Pasar pariwisata akan memberikan gambaran kepada pengelola pariwisata untuk menentukan sasaran wisatawan yang diinginkan baik dimulai dari sasaran penggolongan umur, benua dan gender.

3. Pemilahan potensi pariwisata

Pemetaan potensi pariwisata akan menghasilkan adanya pemilahan potensi mana yang dapat digolongkan sebagai atraksi wisata alam, atraksi wisata budaya dan atraksi wisata buatan 
akan sangat membatu pengelola Desa Wisata Bonto Ujung untuk mempermudah melakukan promosi dan membuat agendaagenda pariwisata seperti event-event pariwisata.

4. Menonjolkan Keunikan Desa Wisata Bonto Ujung Desa Wisata Bonto Ujung harus menonjolkan keunikan mendasar (outstanding universal value) yang memberikan nilai pembeda dari desa-desa wisata lainnya di Provinsi Sulawesi Selatan atau di Indonesia. Keunikan mendasar adalah kekuatan yang tidak tergoyangkan dari pesaing-pesaing lainnya, dan ini akan menjadi nilai jual dan nilai tawar yang sangat tinggi di pasar pariwisata. Keunikan tersebut harus dijadikan headline atau berita utama yang di publish dalam promosi Desa Wisata Bonto Ujung untuk menarik minat wisatawan.

5. Kreativitas dalam packaging

Packaging adalah kombinasi dari jasa dan atraksi wisata yang saling berkaitan dalam satu paket penawaran harga.Packaging atau pengemasan paket wisata di Desa Wisata Bonto Ujung merupakan elemen yang sangat menentukan daya saing produk Desa Wisata Bonto Ujung.Atraksi wisata Desa Wisata Bonto Ujung harus dikemas dalam kemasan yang mampu menarik wisatawan untuk membeli paket wisata tersebut. Badan Pengelola Desa Wisata Bonto Ujung haarus melakukan pengemasan paket yang baik, karena pengemasan paket 
pariwisata yang baik sebagai sukses awal pembuatan suatu paket wisata. Badan Pengelola Desa Wisata Bonto Ujung yang bertanggung jawab mengembangn Desa Wisata Bonto Ujung dituntut untuk melatih insting mereka untuk meracik atraksi wisata menjadi paket yang menarik dan memikat. Adapun paket wisata Desa Wisata Bonto Ujung yang dapat dikemas, yaitu:

1) Paket wisata alam.

> Melihat suasana Alam Pantai Desa Bonto Ujung

Melihat Suasana Persawahan dan Perkebunan

Menyaksikan suasana panen pada musim panen

2) Paket wisata budaya.

Melihat Acara Korongtigi.

Melihat Upacara Pernikahan

3)Paket wisata buatan

Pantai Kelapa Ujung, Nelayan Atraksi, Pakacapi Kelong Makassar

$>$ Paket trekking untuk menikmati suasana alam dan kebudayaan masyarakat Desa Bonto Ujung.

3) Paket Cycling Tour untuk menikmati keindahan alam melalui jalan-jalan utama dan jalur setapak di Desa Bonto Ujung. 
4) Paket Program Pembelajaran(lessong program) seperti art cultural lesson, farm lesson, cooking lesson and Sailor lessong.

5) Paket Program yang memacu keterampilan dan ketangkasan seperti traditional game program village tour program dan outing program

6) Paket wisata spirirtual

Barajanji

\section{Menciptakan Brand}

Brand adalah merek yang dimiliki oleh perusahaan, sedangkan branding adalah kumpulan kegiatan komunikasi yang dilakukan oleh perusahaan dalam rangka proses membangun dan membesarkan brand. Tanpa dilakukannya kegiatan komunikasi kepada konsumen yang disusun dan direncanakan dengan baik, maka sebuah merek tidak akan dikenal dan tidak mempunyai arti apa-apa bagi konsumen atau target konsumennya.

Menurut Kotler (2009:332). merek (brand) merupakan nama, istilah, tanda, simbol, atau rancangan, atau kombinasi dari semuanya, yang dimaksudkan untuk mengidentifikasikan barang atau jasa atau kelompok penjual dan untuk mendiferensiasikannya (membedakan) dari barang atau jasa pesaing. Dengan demikian, sebuah merek adalah produk atau 
jasa penambah dimensi yang dengan cara tertentu mendifrensiasikannya dari produk atau jasa lain yang dirancang untuk memuaskan kebutuhan yang sama. Peranan merek mengidentifikasi sumber atau pembuat produk dan memungkinkan konsumen baik individu atau organisasi untuk menetapkan tanggung jawab pada pembuat atau distributor tertentu.

Dewasa ini semakin banyak daerah yang memiliki potensi pariwisata berusaha melakukan pencitraan dengan memberi penguatan pada simbol atau penanda tertentu.Misal, Pemerintah Kota Surakarta menggunakan branding "Solo the Spirit of Jawa" sebagai upaya merevitalisasi di dataran nilai nilai, filosofi atau pandangan hidup; sistem kehidupan masyarakat dalam berinteraksi dan menjalani kehidupannya, maupun hasil karya atau produk yang dihasilkan dengan semangat budaya tersebut.Bali punya branding "Bali Shanti Shanti Shanti”.Malaysia memiliki branding “ Truly Asia”.dan Indonesia memiliki branding "Wonderfull Indonesia". Gejala pariwisata sesungguhnya tidak terlepas dari kebudayaan sebuah masyarakat, sebab dalam kunjungan wisata, paling tidak terjadi kontak dan interaksi kebudayaan wisatawan dengan kebudayaan penduduk setempat. Setiap daerah wisata mempunyai citra (image) tertentu, yaitu mental maps seseorang 
terhadap suatu destinasi yang di dalamnya mengandung keyakinan, kesan dan persepsi (Pitana dan Gayatri, 2005: 64). Citra yang terbentuk di pasar merupakan kombinasi antara berbagai faktor yang ada pada destinasi yang bersangkutan, seperti iklim, pemandangan alam, keamanan, kesehatan, fasilitas akomodasi, keramahtamahan penduduk, ketersediaan alat alat transportasi di satu pihak, dengan informasi yang diterima oleh calon wisatawan dari berbagai pihak atau dari fantasinya sendiri terhadap pengalamannya selama mengadakan perjalanan wisatanya.

Menurut Buck dan Law dalam Pitana dan Gayatri (2005), pariwisata adalah industri yang berbasiskan citra, karena citra mampu membawa calon wisatawan ke dunia simbol dan makna.Bahkan beberapa ahli pariwisata mengatakan bahwa citra ini memegang peranan yang penting daripada sumberdaya pariwisata yang kasat mata.Dari pengertian ini, maka pembangunan brand image menjadi penting bagi sebuah daerah yang hendak mengembangkan diri sebagai tujuan wisata, termasuk menciptakan branding sebuah desa wisata yang hendak dikembangkan.

Desa Wisata Bonto Ujung sangat perlu mengembangan brand atau merek agar dikenal dan dikenal oleh wisatawan ataupun oleh calon wisatawan. Hal ini sesuai dengan aspirasi 
masyarakat dan pemangku kepentingan pariwisata Desa Bonto Ujung ketika dilakukan FGD yakni penting dan perlunya Desa Bonto Ujung memiliki ikon, yang tidak lain adalah brand atau merek. Untuk membuat brand ini harus melakukan branding yakni proses membuat brand atau merek dan memperkenalkannya kepada masyarakat luas dan calon wisatawan. Jadi tahapannya adalah:

1) Membuat branding desa wisata Bonto Ujung.

Ada beberap alternatif brand yang mungkin dibuat untuk Desa Wisata Bonto Ujung berdasarkan aspirasi masyarakat, yani bahwa Pohon Kelapa yang Ditatanam nenek moyang mereka selalu perpasangan baik 2 maupun 4 pohon ini menandakan hidup harus ada pasangannya "Masyarakat lain berpendapat bahwa Bonto Ujung erat kaitannya dengan Pantai Terpanjang Sepanjang Desa Jadi ikon atau brand dapat berupa Pantai Panjang atau Kelapa Sakti

2) Memperkenalkan/ mempromosikan branding secara offline dan online. Jika brand atau merk atau ikon Desa Wisata Bonto Ujung sudah terbuat, maka harus disosialiasikan ke masyarakat luas termasuk calon-calon wisatawan. Sosialisasi dapat secara off line melalui media cetak dan billboar, ataupun secara online melalui websiste Desa Wisata Bonto Ujung atau Media Sosial lainnya 


\section{J. Selling (Misi Penjualan)}

Dapat dilakukan dengan mengikuti event seperti travel fair, bazar, pameran dengan menawarkan atraksi dan produk wisata yang ada di desa wisata. Selain itu, pada era digital saat ini, desa wisata dapat memanfaatkan media digital sebagai sarana promosi desa wisata melalui:

1. Penggunaan Media Sosial sebagai media promosi misalnya Facebook, Instagram dan Youtube.

2. Menentukan segmentasi wisatawan yang ingin dituju, umumnya berdasarkan umur, dan asal wisatawan. Segmentasini akan menentukan cara berpromosi, sebagai contoh:

a. Facebook: ditujukan bagi keluarga dan wisatawan secara general, umumnya atraksi yang dipasarkan adalah atraksi yang menyenangkan.

b. Instagram: ditujukan bagi wisatawan muda, umumnya atraksi yang dipasarkan adalah atraksi dengan pemandangan indah.

c. Youtube: ditujukan bagi seluruh kalangan wisatawan, umumnya atraksi yang dipasarkan adalah aktivitas yang dapat dilakukan di atraksi wisata tersebut.

d. Twitter.

e. TikTok.

f. Platform aplikasi Desa Wisata.

g. Website Desa.

3. Penggunaan Media Gambar dan Video yang menarik.

4. Penggunaan Bahasa yang persuasif atau menarik minat pembaca untuk membaca lebih jauh. 
5. Pada segi penjualan, digitalisasi dimanfaatkan dengan mendaftarkan atraksi desa wisata ke dalam, website marketplace atau website yang menjual atraksi wisata, seperti traveloka, Agoda, ITX dan lain lain.

6. Membuat website desa wisata, dapat memanfaatkan halaman blog gratis seperti blogspot untuk dapat menuliskan secara lengkap tentang desa wisata.

Pengembangan desa wisata tidak dapat dipisahkan dari penerapan strategi rumusan $3 \mathrm{C}$ yang terdiri dari komitmen pemangku jabatan di daerah dari lini bawah kepala desa sampai dengan gubernur yang digambarkan sebagai CEO komitmen

Setelah adanya CEO komitmen maka penting adanya peningkatan kapasitas pelaku desa wisata dan Masyarakat yaitu digambarkan sebagai competence yang melahirkan champion atau sumber daya manusia desa wisata yang mumpuni dan unggul. Para SDM unggul ini yang nantinya berperan sebagai change agent atau agen perubah dari desa yang unggul dan menjadi trainer of trainer dari champion champion baru yang akan dilahirkan di desa desa yang akan menjadi binaan mereka. 


\section{DAFTAR ISTILAH}

Dalam Pedoman Desa Wisata ini yang dimaksud dengan:

1. Desa adalah desa dan desa adat atau disebut dengan nama lain, selanjutnya disebut Desa, adalah kesatuan masyarakat hukum yang memiliki batas wilayah yang berwenang untuk mengatur dan mengurus Urusan Pemerintahan, kepentingan masyarakat setempat berdasarkan prakarsa masyarakat, hak asal usul dan/atau hak tradisional yang diakui dan dihormati dalam sistem pemerintahan Negara Kesatuan Republik Indonesia.

2. Wisata, adalah kegiatan perjalanan yang dilakukan oleh seorang atau sekelompok orang dengan mengunjungi tempat tertentu untuk tujuan rekreasi, pengembangan pribadi, atau mempelajari keunikan daya tarik wisata yang dikunjungi dalam jangka waktu tertentu.

3. Wisatawan, adalah orang yang melakukan wisata.

4. Kepariwisataan, adalah keseluruhan kegiatan yang terkait dengan pariwisata dan bersifat multi dimensi serta multi disiplin yang muncul sebagai wujud kebutuhan setiap orang dan negara serta interaksi antara wisatawan dan masyarakat setempat, sesama wisatawan, Pemerintah, Pemerintah Daerah, dan pengusaha

5. Pariwisata, adalah berbagai macam kegiatan wisata dan didukung berba fasilitas serta pelayanan yang disediakan oleh masyarakat, pengusaha, Pemerintah, dan Pemerintah Daerah.

6. Daya Tarik Wisata, adalah segala sesuatu yang memiliki keunikan, keindahan, dan nilai yang berupa 
keanekaragaman kekayaan alam, budaya, dan hasil buatan manusia yang menjadi sasaran atau tujuan kunjungan wisatawan.

7. Fasilitas Pariwisata adalah semua jenis sarana yang secara khusus ditujukan untuk mendukung penciptaan kemudahan, kenyamanan, keselamatan wisatawan dalam melakukan kunjungan ke Destinasi Pariwisata.

8. Daerah Tujuan Wisata atau Destinasi Wisata, adalah kawasan geografis yang berada dalam satu atau lebih wilayah administratif yang di dalamnya terdapat daya tarik wisata, fasilitas umum, fasilitas pariwisata, aksesibilitas, serta kehidupan masyarakat yang saling terkait dan melengkapi terwujudnya kepariwisataan.

9. Usaha Pariwisata, adalah usaha yang menyediakan barang dan/atau jasa bagi pemenuhan kebutuhan wisatawan dan penyelenggaraan pariwisata.

10. Pengusaha pariwisata, adalah orang atau sekelompok orang yang melakukan kegiatan usaha pariwisata.

11. Wisata Pedesaan, adalah bentuk aktivitas dimana wisatawan mengamati dan menikmati daya tarik wisata pedesaan.

12. Desa Wisata adalah suatu wilayah dengan Iuasan tertentu dan memiliki potensi keunikan daya tarik wisata yang khas dengan komunitas masyarakatnya yang mampu menciptakan perpaduan berbagai daya tarik wisata dan fasilitas pendukungnya untuk menarik kunjungan wisatawan.

13. Pemberdayaan Masyarakat, adalah upaya untuk meningkatkan kesadaran kapasitas, akses, dan peran masyarakat, baik secara individu maupun kelompok, dalam memajukan kualitas hidup, kemandirian dan kesejahteraan 
melalui kegiatan kepariwisataan.

14. Sumber Daya Manusia (SDM) Pariwisata, adalah tenaga kerja yang pekerjaannya terkait secara langsung dan tidak langsung dengan kegiatan kepariwisataan.

15. Pemerintah Pusat, selanjutnya disebut Pemerintah, adalah Presiden Republik Indonesia yang memegang kekuasaan pemerintahan negara Republik Indonesia yang dibantu oleh wakil presiden dan menteri sebagaimana dimaksud dalam Undang Undang Dasar Negara Republik Indonesia Tahun 1945.

16. Pemerintah Daerah, adalah kepala daerah sebagai unsur penyelenggara Pemerintahan Daerah yang memimpin pelaksanaan urusan pemerintahan yang menjadi kewenangan daerah otonomi 


\section{DAFTAR PUSTAKA}

Dharmawan, I. M. A., Sarjana, I. M., \& Yuhadhari, I. D. A. S. (2014).Strategi Pengembangan Desa Wisata Di Desa Belimbing Kacamatan Pupuan, Kabupaten Tabanan. E-Jurnal Agribisnis Dan Agrowisata , 3(1), 1 - 11.

Kementerian, \& Pariwisata. (2009). Undang Undang No. 10 Tahun 2009 Tentang Kepariwisataan. In Kementerian Pariwisata . Jakarta.

Mahadewi, N. P. E., \& Sudana, I. P. (2017). Model Strategi Pengembangan Desa Wisata Berbasis Masyarakat Di Desa Kenderan Gianyar Bali. Analisis Pariwisata , 17 (1), 41 - 45. Manteiro, M. C. B. (2016). Model Pengembangan Desa Wisata Di Kabupaten Rote Ndao Nusa Tenggara Timur. Bisman Jurnal Bisnis Dan Manajemen , 2(2), 93 - 101.

Murdana, Ida Bagus Putu. (2015). Pengembangan Desa Wisata Rural - Geotourism Berbasis Kearifan Lokal Deng an Metode Sla Untuk Pemberdayaan Masyarakat Miskin Di Kawasan Gunung Batur - Kintamani Kabupaten Bangli. In Eproceeding Undiksa (Pp. 339 - 344). Retrieved From Https://Eproceeding.Undiksha.Ac.Id/Index.Php/Senari/ Article/View/586

Satriawan, B. (2018). Strategi Pengembangan Desa Wisata Di

Keca matan Karangploso Kabupaten Malang. Neo - Bis , 11 (2), 142. Https://Doi.Org/10.21107/Nbs.V11i2.3381

Jurnal, Euis Elih Nurlaelih Dan Karuniawan Puji Wicaksono Pengembangan Agrowisata Di Desa Wisata Tulungrejokota Batu, Jawa Timur Riske Aridiansari*),

Jurnal, I Gede Wyana Lokantara1, 2.Identifikasi Tipologi Destinasi Wisata Dan Strategi Pengembangannya Sebagai Upaya Mewujudkan Pariwisata Kabupate Karangasem Berbasis Wisata Konservasi. 
Muljadi, Andri Warman, 2014. Kepariwisataan dan Perjalanan, Rajagrafindo Persada, Depok.

Yoeti, 1995. Anatomi Pariwisata, Angkasa, Bandung -Undang No.

10 Tahun 2009 tentang Kepariwisataan.

Undang-Undang Nomor 6 Tahun 2014 tentang Desa

Peraturan Pemerintah No. 50 Tahun 2011 tentang Rencana Induk Pembangunan Kepariwisataan Nasional Tahun 2010-2025

Peraturan Pemerintah No. 47 Tahun 2015 tentang Perubahan atas Peraturan

Pemerintah Nomor 43 Tahun 2014

Peraturan Menteri Dalam Negeri No. 44 tahun 2016 tentang Kewenangan Desa

Peraturan Menteri Dalam Negeri Nomor 96 Tahun 2017 tentang Tata Cara Kerjasama Desa di Bidang Pemerintahan Desa

Peraturan Menteri Desa PDTT Nomor 13Tahun 2020 Tentang Prioritas Penggunaan Dana Desa Tahun 2021

Peraturan Menteri Kelautan dan Perikanan No.93 Tahun 2020, tentang Pengembangan Desa Wisata Bahari 